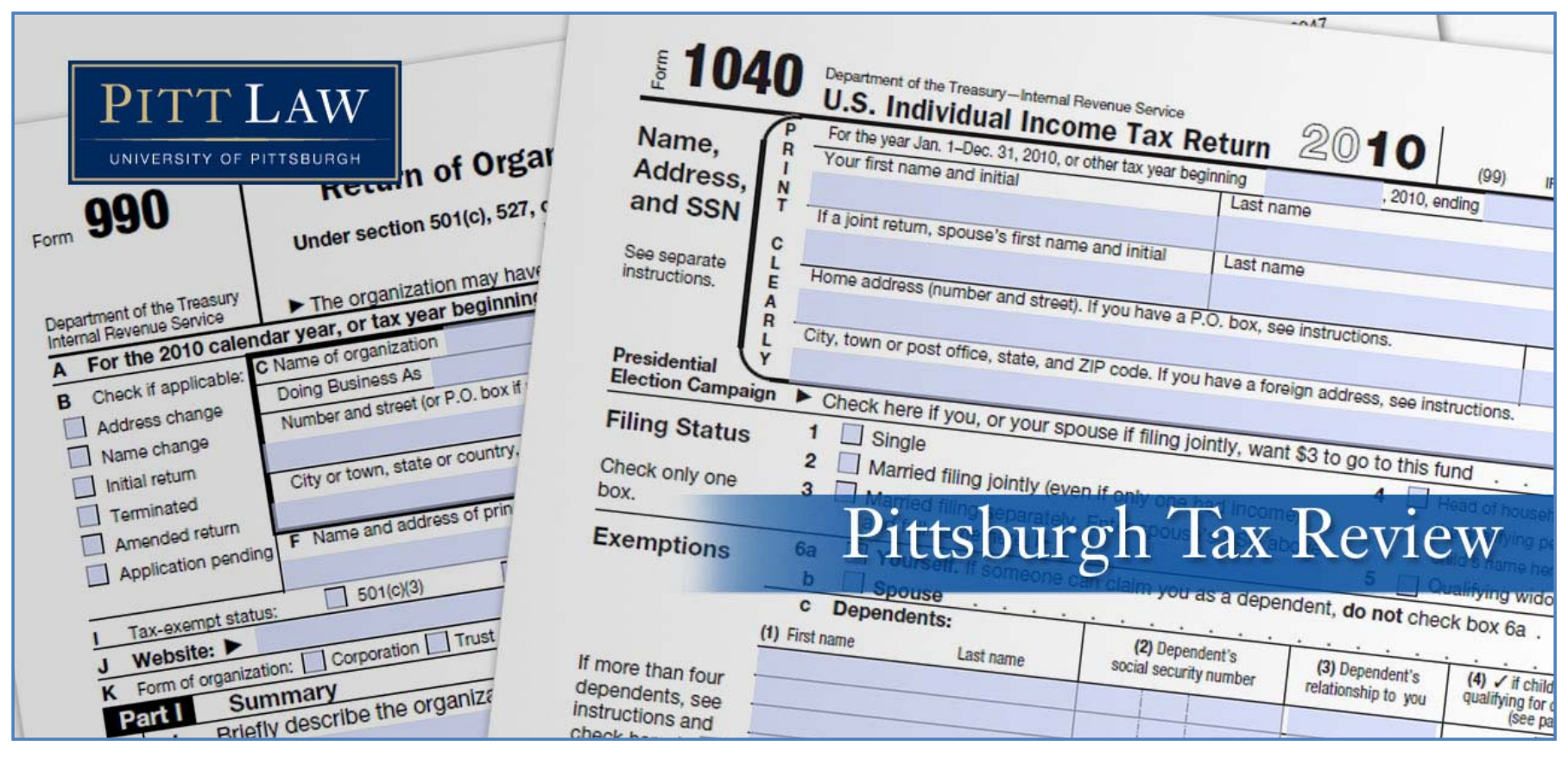

Volume 13 (2015) | ISSN 1932-1821 (print) 1932-1996 (online)

DOI 10.5195/taxreview.2015.41 | http://taxreview.law.pitt.edu

\title{
CHARITABLE ORGANIZATION OVERSIGHT: \\ RULES v. STANDARDS
}

\author{
Philip T. Hackney
}

\section{$((c))$ BY-NG-ND}

This work is licensed under a Creative Commons Attribution-Noncommercial-No Derivative Works 3.0 United States License.

\section{ULIS D-Sente}

This journal is published by the University Library System of the University of Pittsburgh as part of its D-Scribe Digital Publishing Program, and is cosponsored by the University of Pittsburgh Press. 


\title{
CHARITABLE ORGANIZATION OVERSIGHT: RULES v. STANDARDS
}

\author{
Philip T. Hackney *
}

\begin{abstract}
Congress has traditionally utilized standards as a means of communicating charitable tax law in the Code. In the past fifteen years, however, Congress has increasingly turned to rules to stop fraud and abuse in the charitable sector. I review the rules versus standards debate to evaluate this trend. Are congressional rules the best method for regulating the charitable sector? While the complex changing nature of charitable purpose would suggest standards are better, the inadequacy of IRS enforcement and the large number of unsophisticated charitable organizations both augur strongly in favor of rules. Congress, however, is not the ideal institution to implement rules for charitable purpose. The IRS is the better institution generally to institute rules there because of its informational advantage over Congress. Additionally, the IRS can implement rules in a more flexible rule format than can Congress. Still, Congress as a rulemaker makes sense in a few scenarios: (1) where it implements transparent procedural requirements; (2) where it regulates discrete behavior of charitable organization acts; and, (3) where it intends to remove a set of organizations from charitable status through simple rules.
\end{abstract}

${ }^{*}$ James E. \& Betty M. Phillips Associate Professor of Law, Louisiana State University Law Center. This article was made possible in part through a research grant from the LSU Law Center. I thank a number of people who have provided valuable feedback on this article including Nicholas Almendares, Ellen Aprill, Jake Brooks, Sam Brunson, Adam Chodorow, Michael Coenen, Roger Colinvaux, John Devlin, Miranda Perry Fleischer, Anthony Infanti, Lloyd Hitoshi Mayer, Susan Morse, Mirit Eyal-Cohen, Leigh Osofsky, Edward Richards, Scott Sullivan, and Margaret Thomas. I also thank the participants of the 2015 Junior Tax Workshop, the participants of the 2015 AALS Nonprofit Committee Symposium on Charitable Organization Oversight, the Tulane Intellectual Life Workshop, and the participants in the LSU Faculty Scholarship Workshop. I especially thank my research assistants Jeff Butler, Vivian Jeansonne, and Jena Kyle for their dedicated work on this article.

Pitt Tax Review | ISSN 1932-1821 (print) 1932-1996 (online)

DOI 10.5195/taxreview.2015.41 | http://taxreview.law.pitt.edu 


\section{INTRODUCTION}

In a June 2006 press release Senator Charles Grassley lamented that "some individuals are exploiting vagueness or silence in or a lack of enforcement of the laws governing tax-exempt groups to enrich themselves rather than serve the public." Soon after that press release, Senator Grassley inserted a series of narrow yet significant and complex legal changes to the law of tax-exempt charitable organizations into the Pension Protection Act of 2006 ("PPA"). ${ }^{2}$ After the PPA, Senator Grassley sponsored legislation regarding charitable nonprofit hospitals that Congress enacted as part of the Affordable Care Act of 2010 (ACA). ${ }^{3}$

Although these laws applied to a variety of organizational types, they all used technical rules to stop abuses of the charitable sector. ${ }^{4}$ I examine this trend to evaluate whether it is a positive move for charitable organization oversight. I look to the literature on rules and standards, ${ }^{5}$ and conclude that Congress should primarily enact standards and permit the IRS to develop the specific rules. ${ }^{6}$ Not only does the IRS have the expertise, but it also has the

\footnotetext{
${ }^{1}$ Press Release, U.S. Senate Comm. on Fin., Grassley Solicits IRS Comment, Urges Enforcement on Series of Problems in the Tax-Exempt Arena (June 1, 2006), http://www.finance.senate.gov/ newsroom/chairman/release/?id=022c68f3-f4fd-4752-a120-5448b9528ea4.

${ }^{2}$ Pension Protection Act of 2006, Pub. L. No. 109-280, §§ 1211-1245, 120 Stat. 780, 1094-1102.

${ }^{3}$ Patient Protection and Affordable Care Act, Pub. L. No. 111-148, 124 Stat. 119 (2010).

${ }^{4}$ Roger Colinvaux, Charity in the 21st Century: Trending Toward Decay, 11 Fla. TAx REV. 1, 70 (2011) (identifies this trend and argues it is a result of relying on one simple standard for too large a sector and too many different benefits). Others contend that IRS oversight is such a mess that we should strongly consider pulling enforcement responsibility from the IRS and provide it to a new independent agency. Lloyd H. Mayer, "The Better Part of Valour Is Discretion": Should the IRS Change or Surrender Its Oversight of Tax Exempt Organizations, COLUM. J. TAX L. (forthcoming 2016).

${ }^{5}$ See Frederick Schauer, Playing By the Rules: A Philosophical Examination of RuleBASED DeCision-MAKING IN LAW AND In Life (1991); Michael Coenen, Rules Against Rulification, 124 YALE L.J. 576 (2014); Colin S. Diver, The Optimal Precision of Administrative Rules, 93 YALE L.J. 65 (1983) (discussing how to best design rules); Isaac Ehrlich \& Richard A. Posner, An Economic Analysis of Legal Rulemaking, 3 J. LEGAL STUD. 257 (1974); Louis Kaplow, Rules Versus Standards: An Economic Analysis, 42 Duke L.J. 557, 585 (1993); Duncan Kennedy, Form and Substance in Private Law Adjudication, 89 HARV. L. REV. 1685 (1976); Edward Lee, Rules and Standards for Cyberspace, 77 Notre DAME L. ReV. 1275 (2002); Cass Sunstein, Problems with Rules, 83 CALIF. L. REV. 953 (1995).

${ }^{6}$ Admittedly, historically, Congress, the U.S. Dept. of the Treas., and the IRS have overseen charitable tax law in just this way. Professor Colinvaux argues that this approach has led to a vast unwieldy charitable sector and an oversight mess. Colinvaux, supra note 4 , at 6 . He argues that this standard-based system led to scandals that can only be cured by a restructuring of the way we regulate charity at the
}

Pitt Tax Review | ISSN 1932-1821 (print) 1932-1996 (online)

DOI 10.5195/taxreview.2015.41 | http://taxreview.law.pitt.edu 
flexibility to respond to changing conditions. Adopting rules to define charitable purpose at the statutory level is likely to lead to harmfully overinclusive and underinclusive rules. It also is likely to make the regime more difficult for the IRS to administer, ${ }^{7}$ and for a mostly unsophisticated nonprofit sector to navigate. I also contend that the IRS should use more flexible rulemaking, such as revenue rulings and revenue procedures, instead of less flexible regulations. Nevertheless, Congress should consider rules in a few instances: (1) where a process might credibly be thought to improve charitable behavior; (2) where it can regulate a discrete act common to all charitable organizations; and, (3) where it can eliminate a sector of charitable organizations with a simple rule.

This article arose out of a symposium to address whether the regulation of charitable organizations is broken and, if so, whether it can be fixed. In addressing this question, we must first identify a problem. Because the problem is large in scope, this article identifies a relatively narrow one-the effectiveness of tax legislation regarding charitable organizations. ${ }^{8}$ This article asks three questions: (1) what type of legal commands should govern

federal level. Id. He also contends that the recent congressional legislation is only a symptom of a failed system. Id. at 8 . I do not contend here that charitable oversight has been ideal. I only contend that some recent congressional rule-based legislation is likely to make the situation worse rather than better. Whether the charitable tax system itself should be chopped up and divided based on the governmental benefit provided, as Colinvaux suggests, is beyond the scope of this article. However, I do believe we should think broadly in the way Colinvaux recommends; but, I caution, that the rules/standards challenge discussed in this paper should be kept in mind in any such reenvisioning. Also, this Article does not make the claim that Congress should enact standards throughout the Code because of its complexity and the changing nature of society. Nevertheless, some have called for Congress to delegate more rulemaking to the IRS and other related agencies to reap the benefit of the expertise of the IRS. See James R. Hines, Jr. \& Kyle D. Logue, Delegating Tax 10 (Univ. of Michigan Pub. Law Research, Working Paper No. 391, 2014), available at http://papers.ssrn.com/sol3/papers.cfm?abstract_id $=2402047$.

${ }^{7}$ See David Weisbach, Cost of Departures from Formalism: Formalism in Tax Law, 66 U. CHI. L. REV. 860 (1999) (arguing that in contexts where there are thousands of possible complex permutations of a law, a rule based regime can make the law particularly complex); see also U.S. GOV'T ACCOUNTABILITY OFFICE, GAO-15-420R, INTERNAL REVENUE SERVICE: OBSERVATIONS ON IRS OPERATIONS, PLANNING, AND RESOURCES (2015) (describing the severe lack of resources under which the IRS at current operates); TAXPayer AdVOCATE SerV., I.R.S., 2014 AnNual RePORT to CONGRESS (2014) (detailing the particularly severe resource problem of the exempt organizations division of the IRS - the division that oversees charitable organizations).

${ }^{8}$ Although some lament the federalization of charitable oversight, it is quite clear that Congress, the IRS, and federal courts have federalized charitable oversight. See generally Mark L. Ascher, Federalization of the Law of Charity, 67 VAND. L. REV. 1581 (2014).

Pitt Tax Review | ISSN 1932-1821 (print) 1932-1996 (online)

DOI 10.5195/taxreview.2015.41 | http://taxreview.law.pitt.edu 
charitable organizations in the tax arena-rules or standards, (2) if rules are needed, who should develop those rules, and (3) what form should those rules take?

In the rules versus standards debate, a rule is typically defined as a legal command that determines a case before an act, while a standard is a legal command that requires an adjudicator to make a determination after an act. ${ }^{9}$ In considering whether to enact a rule or a standard some scholars focus on where it is most efficient to generate the information needed for a good rule. ${ }^{10}$ The choice to use a rule or a standard affects the complexity and costs of enforcing a particular regime, the likelihood of compliance, and raises issues of the rule of law and democracy. ${ }^{11}$ Finally, separate and apart from questions of efficiency or democracy is the question of which type of legal command is more likely to achieve justice.

The biggest problem with rules is that they tend to generate legal commands that are both overinclusive and underinclusive. ${ }^{12}$ By overinclusive, I mean that the rule will prohibit activities the lawmakers did not intend to prohibit. By underinclusive, I mean that the rule will fail to prohibit activities the lawmakers intended to prohibit. Standards may be superior where that underinclusive and overinclusiveness arises because of technical detail, quickly changing circumstances, or highly complex factual situations. Rules are likely to be superior on any issue that repeats often and is universal. Underinclusion and overinclusion are likely very tolerable in such a situation.

Regarding the first question above, the factors point in two different directions. Standards are superior to rules for two reasons: (1) the legal

\footnotetext{
${ }^{9}$ This is a simplification chosen because it helps in analyzing this question at its simplest level. Anyone who is familiar with law realizes that these legal commands can come in all shapes and sizes. Some possibilities include factors, standards, presumptions, guidelines, principles or analogies. Each of these legal forms possesses both advantages and disadvantages. Some scholars have begun to look at the advantages and disadvantages with some of these methods of developing law. See, e.g., Susan Morse, Safe Harbors, Sure Shipwrecks, 49 U.C. DAVIS L. REV. (forthcoming 2016).

${ }^{10}$ Kaplow, supra note 5, at 585.

${ }^{11}$ SCHAUER, supra note 5, at 159 (discussing the fact that rules allocate power, and that there is often a concern that failing to pass rules allows unelected judges to make the rules rather than allowing the democracy to make the rules).

${ }^{12}$ See, e.g., SCHAUER, supra note 5, at 31-34.
}

Pitt Tax Review | ISSN 1932-1821 (print) 1932-1996 (online) DOI 10.5195/taxreview.2015.41 | http://taxreview.law.pitt.edu 
concept of a charitable organization calls for an analysis of every fact associated with a particular organization over a year period; and (2) the ideal notion of "charitable" expressed by Congress changes over time as technology and society changes. These factors require a complex legal analysis and make good rules difficult to formulate. Four factors suggest rules might be superior: (1) there are a large number of charitable organizations, (2) there is a significant amount of money in the sector, (3) IRS resources to oversee the sector are minimal, and (4) a large portion of the charitable sector is unsophisticated. In weighing these conflicting factors a need to make the system workable seems paramount and therefore some level of rules makes good sense.

Regarding the second question, Congress is generally the wrong institutional player to enact rules to define charitable purpose. ${ }^{13}$ Because the IRS can modify, adjust, and perfect rules utilizing information gained through daily case-by-case analysis, the IRS is much more likely to develop rules that will not be harmfully underinclusive and overinclusive. Because it works daily with the charitable sector, the IRS is likely to have better current information regarding the particular organizational types applying than is Congress. Additionally, the IRS is constantly evaluating the state of charitable law providing it a greater flexibility, and responsiveness, to the changing nature of charitable tax law than Congress. Nevertheless, there are circumstances where Congress is likely a good institution to implement rules. Congress should make rules regarding discrete acts that cross all charitable organizations. It may also be a good institution from which to design simple rules of process. Finally, where it can eliminate a category of charitable organizations with a simple rule, it should consider acting.

As to the third question, the IRS should primarily communicate rules through revenue rulings, and other lower-level guidance items, rather than regulations. This tends to be the historical practice of the IRS in implementing policy in the charitable sector. Once in place, regulations are much harder to change, increasing the potential disconnect between the state of the law on the books and appropriate outcomes. Lower level guidance such

\footnotetext{
${ }^{13}$ This part strongly implicates a question of congressional delegation of rulemaking authority to an agency. More work is needed to fully assess the wisdom of where to properly place this rulemaking authority. However, this analysis based on rules and standards theory does strongly suggest that Congress is not the ideal institutional player for this work.
}

Pitt Tax Review | ISSN 1932-1821 (print) 1932-1996 (online) DOI 10.5195/taxreview.2015.41 | http://taxreview.law.pitt.edu 
as revenue rulings and revenue procedures tend to be easier to change. This strategy will maintain the information and flexibility advantage of the IRS in rulemaking, but also provide a satisfactory level of certainty.

Admittedly, there are problems with this plan. It leaves a high degree of discretion to unelected bureaucrats, and it might lessen reliance and stability, two important components of a rule-based regime. ${ }^{14}$ While many might object to the suggested high degree of discretion granted to the Service here as anti-democratic, ${ }^{15}$ Congress, the President, and the courts have the ability to check the Service's rulemaking. ${ }^{16}$ This should alleviate, in part, such democratic concerns. Additionally, regular guidance from the IRS through revenue rulings could balance taxpayer needs for reliance and stability against the equally important need for flexibility and good information. ${ }^{17}$

A further implication of this analysis is that the IRS and the Treasury Department should put a significant amount of its resources towards implementing rules. Many commentators believe that the IRS has not provided enough charitable tax law guidance over the past twenty years. ${ }^{18}$ Under this analysis, the IRS would be wise to spend its resources primarily on revenue rulings and revenue procedures rather than on much more time consuming regulations.

In light of these normative conclusions, this article reviews and critiques EO legislation regarding credit counseling organizations, supporting organizations, and hospitals. Congress employed relatively detailed rules for each of these legislative actions in order to stem perceived abuses by many in those industry sectors. These complex rules should prove to be harmful to

${ }^{14}$ SCHAUER, supra note 5 , at $155-58$.

${ }^{15}$ See, e.g., Bob Jones Univ. v. United States, 461 U.S. 574, 606 (1983) (Powell, J., concurring) (stating that he is concerned about the authority granted to the IRS to determine fundamental public policy presumably from a concern about the democratic implications).

${ }^{16}$ See Hines \& Logue, supra note 6 (making the case that providing delegation authority to the IRS is not that anti-democratic because of the checks of Congress, but also the fact that the President is elected and ultimately controls the rulemaking at the agency level).

${ }^{17}$ This article leaves to another article whether the IRS should follow Administrative Procedure Act requirements of notice and comment when publishing revenue rulings and procedures, as well as the correct level of deference courts should extend to these IRS guidance items, in the charitable organization realm. See Kristin E. Hickman, Unpacking the Force of Law, 66 VAND. L. REV. 465 (2013).

${ }^{18}$ See, e.g., Mayer, supra note 4.

Pitt Tax Review | ISSN 1932-1821 (print) 1932-1996 (online) DOI 10.5195/taxreview.2015.41 | http://taxreview.law.pitt.edu 
the oversight of this sector by imposing rules that will be both underinclusive and overinclusive, overly complicated for both organizations and IRS enforcement, and likely to take away the flexibility of the IRS in overseeing the charitable sector.

This Article raises a number of separate but related issues. The question of who should develop rules - Congress or an agency - raises the question of the delegation power of Congress. The delegation debate is quite similar to the rules vs. standards debate. The two focus on questions of democracy and which institution is most likely to have the best ability from an informational perspective to get the law right. Those who argue for broad delegation argue (1) that agencies have greater knowledge and expertise than their congressional counterpart, and (2) the agency process can ensure the law gets made. Those who argue against broad delegation claim that agency based law is less legitimate and less accountable than law made by Congress. ${ }^{19}$ The delegation debate also raises questions about agency discretionary power, ${ }^{20}$ and the legal validity of the form of rulemaking for which this Article advocates: non-regulatory modes of guidance. ${ }^{21}$ Because this latter issue is particularly messy and challenging, but highly important to the question of how effective less formal guidance might be, I hope to address this matter of delegation and tax exempt charitable organization guidance in a separate article.

Part II of this article reviews charitable tax law. It also examines in detail the changes made to that law over the past fifteen years with a focus on three particular rule changes through legislation including: (1) credit counseling organizations; (2) hospitals; and (3) supporting organizations. Part III reviews the literature regarding rules and standards. Part IV considers the implications of the rules and standards literature on (1) whether rules or

${ }^{19}$ For a discussion of these issues, see Hines \& Logue, supra note 6; Jerry L. Mashaw, Prodelegation: Why Administrators Should Make Political Decisions, 1 J.L. ECON. \& ORG. 81 (1985); Peter H. Schuck, Delegation and Democracy: Comments on David Schoenbrod, 20 CARDOzo L. ReV. 775 (1999); DAVID SCHOENBROD, POWER WITHOUT RESPONSIBILITY (1993).

${ }^{20}$ Kenneth Culp Davis, Discretionary Justice (1969); see also Philip T. Hackney, Should the IRS Never "Target" Taxpayers: An Examination of the IRS Tea Party Affair, 49 VAL. U. L. REV. 453 (2015) (considering the degree of discretion granted to the IRS by Congress over its determination function).

${ }^{21}$ See, e.g., Hickman, supra note 17, at 471 (examining the legal force of "I.R.B. guidance" such as revenue rulings).

Pitt Tax Review | ISSN 1932-1821 (print) 1932-1996 (online) DOI 10.5195/taxreview.2015.41 | http://taxreview.law.pitt.edu 
standards should be enacted for charitable tax law, (2) if rules should be implemented, who should implement them, and (3) what form those rules should take. Part $\mathrm{V}$ applies this analysis to critique the chosen pieces of recent tax-exempt legislation. Part VI concludes.

\section{CHARITABLE TAX LAW}

\section{A. What Is the Rationale of Charitable Tax Law?}

At a basic level, the primary purpose of charitable tax law must be to ensure that individuals all bear the proper income tax burden. In other words, it is aimed at helping to define the income tax base. The initial justification for charitable tax exemption held that we provide a subsidy to organizations that provide a public benefit that is at least equal to the tax given up. This public benefit justification has little content though. Efforts have been made to define that necessary public benefit. The most accepted theory is Hansmann's market failure theory that posits we should provide tax exemption to those organizations that are providing a public good or solving an important contract failure. ${ }^{22}$ Some have suggested that encouraging altruism is a sufficient good in itself, ${ }^{23}$ while others have contended that charitable organizations simply do not have income to speak of. ${ }^{24}$ There does seem to be consensus that the income of charitable organizations is generally not a part of the tax base.

However, because of the role that the IRS plays in reviewing charitable organizations nationally, many also see the role of the IRS as a regulator of the charitable sector. ${ }^{25}$ Whether it is a legitimate rationale or not, Congress

\footnotetext{
${ }^{22}$ Henry Hansmann, The Rationale for Exempting Nonprofit Organizations from Corporate Income Taxation, 91 YALE L.J. 54 (1981).

${ }^{23}$ Rob Atkinson, Altruism in Nonprofit Organizations, 31 B.C. L. REV. 501 (1990). Others have suggested that it is important to consider distributive justice concerns as much as efficiency and pluralism concerns emphasized by other scholars. Miranda Perry Fleischer, Theorizing the Charitable Tax Subsidies: The Role of Distributive Justice, 87 WASH. U. L. REV. 505 (2010).

${ }^{24}$ Boris Bittker \& George Rahdert, The Exemption of Nonprofit Organizations from Federal Income Taxation, 85 YALE L.J. 299 (1976).

${ }^{25}$ John Simon et al., The Federal Tax Treatment of Charitable Organizations, in THE NONPROFIT SECTOR: A ReSEARCH HANDBOOK 267 (Walter W. Powell \& Richard Steinberg eds., 2d ed. 2006) (discussing the regulatory function of the income tax exempt organization system); see also Hackney, supra note 20 (arguing that one justification for charitable tax exemption might be to regulate charitable
}

Pitt Tax Review | ISSN 1932-1821 (print) 1932-1996 (online) DOI 10.5195/taxreview.2015.41 | http://taxreview.law.pitt.edu 
uses charitable tax law to regulate the charitable sector. This means there are at least two primary purposes of charitable tax law that our legislature might intend. The first focuses on making value judgments about organizations that are worthy of not paying taxes; the second focuses on making value judgments about whether a particular act is charitable in nature. This is a combination of the support and equity functions of the tax-exempt system identified by Simon, Chisholm and Dale. ${ }^{26}$

There is, too, another purpose that charitable tax law arguably serves: to enhance pluralism. ${ }^{27}$ Justice Powell spoke clearly about this role in a concurrence in Bob Jones University.

As Justice Brennan has observed, private, nonprofit groups receive tax exemptions because "each group contributes to the diversity of association, viewpoint, and enterprise essential to a vigorous, pluralistic society." Far from representing an effort to reinforce any perceived "common community conscience," the provision of tax exemptions to nonprofit groups is one indispensable means of limiting the influence of governmental orthodoxy on important areas of community life. ${ }^{28}$

Continuing in this vein, Burton Weisbrod has argued that the nonprofit sector is useful to solve government failure to provide public goods at an optimal level. ${ }^{29}$ Because the government will only provide for the needs of the median voter, nonprofits can provide the services and needs of those on

organizations). However, states are generally expected to regulate charitable organizations. Thus, some scholars find the idea that the IRS might engage in the regulation of charitable organizations to be problematic. See, e.g., James J. Fishman, Stealth Preemption: The IRS's Nonprofit Corporate Governance Initiative, 29 VA. TAX REV. 545, 548-49 (2010).

${ }^{26}$ Simon et al., supra note 25 .

${ }^{27}$ See Lester M. SAlamon, America's NonProfit Sector: A Primer 8-9 (1992); David A. Brennen, A Diversity Theory of Charitable Tax Exemption-Beyond Efficiency, Through Critical Race Theory, Toward Diversity, 4 PITT. TAX Rev. 1, 15 (2006); cf. Philip Hackney, Taxing the Unheavenly Chorus: Why Section 501(c)(6) Trade Associations are Undeserving of Tax Exemption, 92 DENV. U. L. REV. 265 (2015) (questioning whether tax exemption always enhances pluralism).

${ }^{28}$ Bob Jones Univ. v. United States, 461 U.S. 574, 609 (1983) (quoting Walz v. Tax Comm'n, 397 U.S. 664, 689 (1970) (Brennan, J., concurring)). (1977).

${ }^{29}$ Burton A. Weisbrod, The Voluntary NonProfit SeCtor: AN ECONOMiC ANALYsis 66-67

Pitt Tax Review | ISSN 1932-1821 (print) 1932-1996 (online) DOI 10.5195/taxreview.2015.41 | http://taxreview.law.pitt.edu 
the margins. ${ }^{30}$ If in fact our charitable organizations are fulfilling this pluralistic goal, we should expect charitable tax law to change rather than to stay static.

Pluralism posits that society is made up of many interests whose needs can be satisfied through political means. ${ }^{31}$ Groups form to represent interests, such as business or labor. Those groups then request that the government provide certain goods and services. As David Truman envisioned, this system works in waves. ${ }^{32}$ As one interest is fulfilled, another interest will arise seeking to take back something that was lost to the other group. Thus, through time, we should see new and different groups forming in this pluralistic fashion. In fact, if we accept that pluralism should be a part of our goal for charitable tax law, we should also build a law that is flexible enough to accept such changes in our political and social life. Otherwise, the system will in fact not support pluralism.

\section{B. Tax Exempt Charitable Organization Law}

When Congress enacted the Income Tax in 1913, it included an exemption from income tax for charitable organizations. ${ }^{33}$ This exemption can also be found in earlier iterations of the income tax and the corporate income tax in the United States. ${ }^{34}$ Congress absolved entities with a particular organizational structure and purpose from an obligation to pay the income tax, but required all other persons and entities to pay tax on income whether at the organizational level ${ }^{35}$ or at the individual level. ${ }^{36}$

${ }^{30}$ WeISBROD, supra note 29, at 66-67; cf. Brian Galle, The Role of Charity in a Federal System, 53 WM. \& MARY L. REV. 777, 803 (2012) (arguing that Weisbrod's theory based on the median voter ignores public choice theory which posits that the median voter does not always control).

${ }^{31}$ SCOTt H. Ainsworth, ANALyZING INTEREST Groups 5 (2001).

${ }^{32}$ David B. Truman, The Governmental Process 59 (1951).

${ }^{33}$ Tariff Act, ch. 16, 38 Stat. 114, 172 (1913).

${ }^{34}$ For a history of the corporate income tax and exemptions therefrom, see Philip T. Hackney, What We Talk About When We Talk About Tax Exemption, 33 VA. TAX REV. 115, 131-35 (2013).

${ }^{35}$ I.R.C. $§ 11$.

${ }^{36} I d . \S 1$.

Pitt Tax Review | ISSN 1932-1821 (print) 1932-1996 (online) DOI 10.5195/taxreview.2015.41 | http://taxreview.law.pitt.edu 
Although most Americans probably think that the Code consists solely of detailed rules, in fact Congress has generally employed broad standards in the Code to govern charitable organizations. To be described in $\S 501(\mathrm{c})(3)$, an organization must (1) meet a certain organizational form; (2) be organized and operated exclusively for a charitable purpose; and (3) prohibit the inurement of net earnings to any private shareholder or individual. ${ }^{37}$ Later, Congress added a prohibition on engaging in more than a substantial amount of lobbying $^{38}$ and completely prohibited the intervening in a political campaign. ${ }^{39}$ While some of $\S 501$ (c)(3) works in a rule-like manner, arguably (1) and (3) above, the heart of $\S 501(\mathrm{c})(3)$ is the mandate to operate exclusively for a charitable purpose. On this issue, Congress provided no explicit guidance in legislative history or otherwise. It established a standard with the flexibility of the common law legal concept of charity. ${ }^{40}$

The IRS provides some modest content to the standard in regulations by defining charitable, ${ }^{41}$ educational, ${ }^{42}$ scientific, ${ }^{43}$ and other related terms. However, it has primarily stayed at the broad standard level in its regulations. For instance, the IRS states that the term charitable has the meaning given "in its generally accepted legal sense." 44 The IRS often interprets this choice to mean that it adopted the broad standard developed under the law of charitable trusts. ${ }^{45}$ The IRS typically includes examples in its regulations that provide some rules; however, many complain that those examples only

${ }^{37}$ Id. $\S 501(\mathrm{c})(3)$.

38 Joint COMm. On TAXation, JCX-29-05, Historical DEVELOPMENT AND PRESENT LaW of THE FEDERAL TAX EXEMPTION FOR CHARITIES AND OTHER TAX-EXEMPT ORGANIZATIONS (2005).

${ }^{39} \mathrm{Id}$. at 59.

${ }^{40}$ John P. Persons et al., Criteria for Exemption Under Section 501(c)(3), in 4 ReSEARCH PAPERS: Sponsored by the Commission on Private Philanthropy AND PUBliC NeEds 1909, 1921-22 (1977).

${ }^{41}$ Treas. Reg. § 1.501(c)(3)-1(d)(2) (as amended in 2014).

${ }^{42} I d . \S 1.501(\mathrm{c})(3)-1(\mathrm{~d})(3)$.

${ }^{43} I d . \S 1.501(\mathrm{c})(3)-1(\mathrm{~d})(5)$.

${ }^{44}$ Id. $\S 1.501(\mathrm{c})(3)-1(\mathrm{~d})(2)$.

${ }^{45}$ See, e.g., Rev. Rul. 69-545, 1969-2 C.B. 117 (1969) (turning to the law of charitable trusts to determine the meaning of charitable in its "generally accepted legal sense of the word").

Pitt Tax Review | ISSN 1932-1821 (print) 1932-1996 (online) DOI 10.5195/taxreview.2015.41 | http://taxreview.law.pitt.edu 
illustrate the very clear situations that no one would question anyway. This means that the examples often do little work to define charitable purpose.

While the Code and regulations regarding charitable organizations have historically relied on broad standards, the IRS has created rules to implement these standards. The IRS has done this primarily through less formal guidance, such as revenue rulings and revenue procedures. ${ }^{46}$ These guidance items announce rules that constrain the discretion of the IRS and provide more certainty to the charitable sector. ${ }^{47}$ For instance, in Rev. Rul. 76-204 the IRS ruled that an organization that acquires and preserves ecologically significant undeveloped land furthers a national policy of preserving natural resources and thereby serves a charitable purpose through advancing education and science. ${ }^{48}$ Rev. Rul. $75-74$ provides that a public interest law firm that litigates cases that provides representation in cases of important public interest that are not economically feasible for private firms operates for a charitable purpose. In the public interest law firm line of business, the IRS additionally issued a revenue procedure that provided specific rule-based guidelines to operate these firms such as specific rules on the acceptance of fees and how much in fees they could accept. ${ }^{49}$ There are hundreds of other guidance items along these lines.

The IRS develops these guidance items in large part based on its agents' interactions with charitable organizations in adjudications. For instance, the IRS constructed its principal revenue ruling on hospitals in 1969 based upon its agents' work in assessing lots of hospitals over many years. ${ }^{50}$ The agents

${ }^{46}$ See, e.g., id. (establishing the community benefit rule for hospitals trying to qualify as charitable organizations); Rev. Rul. 70-585, 1970-2 C.B. 115 (establishing rules for organizations trying to qualify as charitable by providing housing).

${ }^{47}$ A review of the IRS Exempt Organization Continuing Professional Education Topical Index gives a decent idea as to the breath of the industries the IRS and the Treasury Department and the courts have opined upon and provided greater stability and reliance for taxpayers. http://www.irs.gov/pub/irstege/cpeindexbytopic.pdf. Arguably, in many instances some of the revenue rulings discussed in those documents may be thought to have established sets of factors rather than establishing rules per se. However, I leave that question for below in discussing the nature of rules and the necessary open texture that is left in any rule. See, e.g., SCHAUER, supra note 5, at 34-37.

${ }^{48}$ Rev. Rul. 78-384, 1978-2 C.B. 174.

${ }^{49}$ Rev. Proc. 92-59, 1992-1 C.B. 411.

${ }^{50}$ Rev. Rul. 69-545, 1969-2 C.B. 117.

Pitt Tax Review | ISSN 1932-1821 (print) 1932-1996 (online) DOI 10.5195/taxreview.2015.41 | http://taxreview.law.pitt.edu 
audit and review the applications of charitable organizations. ${ }^{51}$ Charitable organizations also seek private letter rulings on transactions they plan to enter. These daily adjudications can provide guidance both to the IRS and the public. While private letter rulings are only applicable to the organization that received the ruling, the private letter rulings are generally available to the public and give an understanding of the direction the IRS might choose under a particular circumstance. More importantly for this project, these regular interactions can provide the employees of the IRS deep knowledge of charitable organizations and the law through a case-by-case method.

Courts fill in some of those rules as well. ${ }^{52}$ Congress provides charitable organizations the right to challenge any IRS decision denying the organization charitable status. ${ }^{53}$ A charitable organization can also challenge IRS decisions in court by refusing to pay a tax and then seeking a refund from the IRS based on the organization's tax-exempt status. ${ }^{54}$ Utilizing this power of review, for instance, courts have played a role in defining the contours of charitable organizations and healthcare. ${ }^{55}$ Within the healthcare sphere, courts determined that health maintenance organizations that sold insurance but also provided actual care through a clinic with doctors could qualify for charitable status. ${ }^{56}$ In another instance, a court determined that a health plan by itself, without any substantial charitable activity such as operating a clinic or providing services for free could not qualify for charitable status. ${ }^{57}$

Courts can sometimes interrupt the coherency that might be developed via IRS policy. For instance, as will be discussed more below, a court case rejecting an IRS ruling regarding a credit counseling organization may have

\footnotetext{
${ }^{51}$ Hackney, supra note 20.

${ }^{52}$ See, e.g., Better Bus. Bureau v. United States, 326 U.S. 279 (1945) (establishing that "exclusively operating for an exempt purpose" meant "no more than insubstantial"); Bob Jones Univ. v. United States, 461 U.S. 574 (1983) (confirming that there is a public policy limitation on the activities of charitable organizations under the Code).

${ }^{53}$ I.R.C. $\S 7428$.

${ }^{54}$ I.R.C. $\S 7422$.

${ }^{55}$ See, e.g., Sound Health Ass'n v. Comm'r, 71 T.C. 158 (1978); Geisinger Health Plan v. Comm'r, 985 F.2d 1210 (3d Cir. 1993); IHC Health Plans, Inc. v. Comm'r, 325 F.3d 1188 (10th Cir. 2003).

${ }^{56}$ Sound Health Ass'n, 71 T.C 158.

${ }^{57}$ IHC Health Plans, 325 F.3d 1188.
}

Pitt Tax Review | ISSN 1932-1821 (print) 1932-1996 (online) DOI 10.5195/taxreview.2015.41 | http://taxreview.law.pitt.edu 
led in part to the abuse of charitable law by credit counseling organizations. ${ }^{58}$ The IRS had limited charitable credit counseling organizations to serving the poor and low income. The court found that ruling too narrow and reversed the IRS ruling. Nevertheless, court review obviously serves as an important check on the power of the IRS, and at the same time, that review serves to develop the rules regarding charitable organizations on a case-by-case basis.

While Congress has mostly used standards in the Code to govern charitable organizations, it has used rules in some instances. In 1969, Congress enacted a detailed rule-based regime to govern private foundations. Private foundations are a subset of charitable organizations that do not receive broad public support. ${ }^{59}$ For instance, the Bill \& Melinda Gates Foundation and the Ford Foundation are private foundations because they received almost all of their support from one family. Private foundations are subject to detailed rules that focus in on a required payout regime. ${ }^{60}$ To prove they are charitable, they must annually make grants of a significant percentage of their assets to qualified charitable causes. ${ }^{61}$ They are subjected to stringent rules regarding self-dealing. ${ }^{62}$ Congress has also arguably chosen to utilize rules to implement the unrelated business income tax. ${ }^{63}$

Congress tends to use rules for charitable tax law primarily in instances where it is able to focus on strict numbers or individual acts. For instance, Congress uses rules in part to govern private foundations where it is focusing primarily on numbers. Foundations must pay out a specific amount of money to charitable purposes annually to qualify. Congress unsurprisingly also adopts rules to govern the unrelated business income tax, again a matter of numbers. Although there are issues to still sort out, the UBIT provisions have a relatively high level of specificity as to what items go into income or not. Congress uses rules for discrete acts too. It uses rules to govern private

\footnotetext{
${ }^{58}$ Consumer Credit Counseling Serv. of Ala., Inc. v. United States, 78-2 U.S.T.C. ๆ 9660, 44 A.F.T.R.2d 79-5122 (D.D.C. 1978).

${ }^{59}$ I.R.C. $\S 509$.

${ }^{60} I d . \S \S 4942,4945$.

${ }^{61}$ I.R.C. $\S \S 4942,4945$.

${ }^{62}$ Id. $\S 4941$.

${ }^{63}$ Id. $\S \S 511-514$.
}

Pitt Tax Review | ISSN 1932-1821 (print) 1932-1996 (online) DOI 10.5195/taxreview.2015.41 | http://taxreview.law.pitt.edu 
foundation excise taxes such as for self-dealing. If a manager engages in a self-dealing transaction we simply determine the amount involved in the discrete act and we apply a tax.

\section{Parties Regulated/State of Enforcement}

What does the regulatory environment look like in the charitable sector? It generates around five percent of GDP. ${ }^{64}$ More than two trillion dollars of total assets held in the charitable sector are held in the health and education fields. ${ }^{65}$ Almost $70 \%$ of the individual organizations hold less than one million dollars in assets, while less than three percent of charitable organizations hold $80 \%$ of the assets. ${ }^{66}$ There were around 1.2 million registered public charities in 2012 according to IRS statistics. ${ }^{67}$ This likely does not come close to counting all charitable organizations. This is because churches and small organizations, the combination of which makes up a big part of the charitable sector, need not register. ${ }^{68}$ Of the total number of registered organizations, only 274,000 filed information returns. ${ }^{69}$ Approximately 85,000 of those organizations filed a Form 990-EZ. ${ }^{70}$ The Form $990-\mathrm{EZ}$ is filed by small organizations with annual gross receipts normally less than $\$ 200,000$ and assets no more than $\$ 500,000 .^{71}$ Organizations with annual gross receipts of an amount normally less than

${ }^{64}$ Brice S. McKeever \& Sarah L. Pettijohn, The Nonprofit Sector in Brief 2014, URB. INST. (Oct. 2014), http://www.urban.org/sites/default/files/alfresco/publication-pdfs/413277-The-Nonprofit-Sectorin-Brief--.PDF.

${ }^{65}$ U.S. Gov'T ACCOUNTABILITY OfFice, GAO-15-164, TAX EXEMPT ORganizations: BetTER COMPLIANCE INDICATORS AND DATA, AND MORE COLLABORATION WITH STATE REGUlators WOULD Strengthen Oversight OF Charitable ORganizations 14 (2014).

${ }^{66} I d$.

${ }^{67}$ See McKeever \& Pettijohn, supra note 64.

${ }^{68}$ I.R.C. $\S 508$.

${ }^{69}$ U.S. Gov'T ACCOUNTABILITY OFFICE, supra note 65, at 9.

${ }^{70} \mathrm{Id}$.

${ }^{71}$ Id. at 5-6.

Pitt Tax Review | ISSN 1932-1821 (print) 1932-1996 (online) DOI 10.5195/taxreview.2015.41 | http://taxreview.law.pitt.edu 
$\$ 50,000$ need not file an information return, but instead must file a $990-\mathrm{N}$ every three years. ${ }^{72}$ In 2014, over 470,000 organizations filed Form 990-Ns. ${ }^{73}$

The vast majority of charitable organizations are small organizations. Charitable organizations held $\$ 2.99$ trillion in assets in $2012 .{ }^{74}$ Of that amount though, the health and education sector held more than two trillion dollars. ${ }^{75}$ Almost $70 \%$ of the individual organizations hold less than one million dollars in assets, while less than three percent of charitable organizations held $80 \%$ of the assets. ${ }^{76}$ From this information, it seems reasonable to conclude that about $70 \%$ to $80 \%$ of charitable organizations are unsophisticated and have little access to legal counsel. Conversely, perhaps twenty to thirty percent of the charitable world possesses some amount of resources that may enable them to seek counsel. In fact, there are a few categories of the charitable sector where the resources are fairly significant. This would include the hospital sector, health maintenance organizations, universities, and the foundation world. This stark divergence in sophistication, size, and money likely makes drafting rules and regulating the charitable sector highly challenging.

What about the IRS and its resources? After the Tea Party affair, ${ }^{77}$ it has been well documented that the enforcement resources are inadequate. ${ }^{78}$

${ }^{72}$ InTERnal ReVEnue SERV., ANNuAl EleCtronic Filing ReQuirement For SMAll EXEMPT ORGANIZATIONS-FORM 990-N (E-POSTCARD) (Apr. 21, 2015), http://www.irs.gov/Charities-\&-NonProfits/Annual-Electronic-Filing-Requirement-for-Small-Exempt-Organizations-Form-990-N-(ePostcard); see U.S. GOV’T ACCOUNTABILITY OFFICE, supra note 65.

${ }^{73}$ INTERNAL REVENUE SERV., supra note 72.

${ }^{74}$ McKeever \& Pettijohn, supra note 64.

${ }^{75}$ U.S. GOV'T ACCOUNTABILITY OFFICE, supra note 65.

${ }^{76} I d$.

${ }^{77}$ Hackney, supra note 20 (evaluating the controversy over the IRS applying particularly close scrutiny to conservative organizations such as the Tea Party seeking to be declared as tax exempt by the IRS because described as social welfare organizations).

${ }^{78}$ See U.S. Gov'T ACCOUNTABILITY OFFICE, supra note 7 (describing the severe lack of resources under which the IRS at current operates); TAXPAYER ADVOCATE SERV., supra note 7 (detailing the particularly severe resource problem of the exempt organizations division of the IRS - the division that oversees charitable organizations).

Pitt Tax Review | ISSN 1932-1821 (print) 1932-1996 (online) DOI 10.5195/taxreview.2015.41 | http://taxreview.law.pitt.edu 
Additionally, the audit rate is quite low. ${ }^{79}$ In most years the IRS audits less than one percent of the existing charitable organization population. ${ }^{80}$ Fewer than 900 employees work in the IRS's EO division to oversee over one million organizations of various sophistication and ability. ${ }^{81}$ Thus, the IRS looks like a typical agency that has too few resources to carry out its mandate. It operates two primary programs: (1) a determinations system where it evaluates whether to grant an organization a letter stating that the organization is tax exempt; and (2) an examination system where it annually examines nonprofits through audits and other reviews of their materials. It appears that the IRS is neither able to closely monitor the determination system, nor to stay on top of its examination system.

\section{The Recent Push to Regulate Abuses of Charity Through the Code}

With notable exceptions, Congress has generally left it to the IRS to write charitable tax law rules. However, in the last ten years, Congress has taken a more rule-based approach. ${ }^{82}$ The motivation for the legislation seems to be a desire to stop abuses of the charitable contribution deduction, but also a desire to hinder charitable organizations from taking advantage of vulnerable populations. This part briefly reviews three select pieces of legislation enacted over the past ten years.

${ }^{79}$ See Charity and Nonprofit Audits (July 17, 2015), http://www.irs.gov/Charities-\&-NonProfits/Exempt-Organizations-Audit-Process (describing the IRS EO division audit process for charitable organizations).

${ }^{80}$ U.S. GOV'T ACCOUNTABILITY OFFICE, supra note 65.

${ }^{81}$ InTERNAL REVENUE SERV., IRS EXEMPT ORGANIZATIONS: FY 2012 ANNUAL REPORT \& FY 2013 WORKPLAN, at 14 (2013).

${ }^{82}$ This is not to say that Congress has always left the charitable regime alone. In 1969, Congress imposed significant rules on the sector. That attention was mostly focused on delineating private foundations from public charities, and imposing strict excise taxes on the former. That was not focused on any particular charitable industry, but more focused on the likely independent public governance, or lack thereof, of organizations identified as private foundations. Congress also has generally eliminated insurance from qualifying as charitable and has added a more rule-based regime to govern excess benefit transactions. I.R.C. $\S \S 501(\mathrm{~m}), 4958$. The more recent legislation is particularly interesting for its foray into governing the rules regarding qualifying as a charitable organization in a particular industry.

Pitt Tax Review | ISSN 1932-1821 (print) 1932-1996 (online) DOI 10.5195/taxreview.2015.41 | http://taxreview.law.pitt.edu 
In 2006, as part of the PPA, ${ }^{83}$ Senator Grassley succeeded in enacting a number of additional somewhat eclectic, but highly complex, provisions directed at the charitable sector. Two of the provisions included stricter limitations on "credit counseling organizations," 84 and more defined rules regarding supporting organizations to ensure these organizations are genuinely providing benefits and services to charitable organizations. ${ }^{85}$ In 2010 , Senator Grassley was also instrumental in enacting $\S 501(\mathrm{r})$, which imposed stricter rules on the operation of nonprofit hospitals claiming charitable status. Grassley inserted the new nonprofit hospital legislation into the ACA signed by President Obama in 2010. More information regarding each of these organizations is provided below in Part $\mathrm{V}$ along with an evaluation of the legislation.

Credit Counseling Legislation: In reaction to an understanding that many credit counseling organizations were engaged in abuse of debtors, Congress enacted $\S 501(\mathrm{q})$ to closely restrict behavior of credit counseling organizations. If an organization provides substantial credit counseling services, it is required to meet a laundry list of requirements: it must (1) provide services "narrowly tailored" to the specific needs and circumstances of consumers; (2) not make of or negotiate loans for debtors; (3) help creditors improve their credit only incidentally to their counseling regarding debt; (4) provide services without regard to the ability of a debtor to pay for the services; (5) implement a fee policy that is generally not based upon the percentage of debt a debtor owes; (6) appoint an independent community based board of directors; (7) not own more than a certain portion of a business that is engaged in lending money; (8) not pay or receive money for referrals; (9) not solicit contributions from consumers in an initial meeting to seek assistance; and (10) not receive more than $50 \%$ of its revenues from creditors associated with debt management plans. ${ }^{86}$ On the rule to standard continuum, these are certainly on the rule side of the continuum.

Hospital Legislation: In 2010, Senator Grassley successfully added to the ACA, and Congress passed, a new Code section detailing requirements

\footnotetext{
${ }^{83}$ Pension Protection Act of 2006, Pub. L. No. 109-280, 120 Stat. 780.

${ }^{84}$ I.R.C. $§ 501(q)$.

${ }^{85} \mathrm{Id} . \S \S 509(\mathrm{a})(3), 4958,4966$.

${ }^{86}$ I.R.C. $\S 501(\mathrm{q})$.
}

Pitt Tax Review | ISSN 1932-1821 (print) 1932-1996 (online) DOI 10.5195/taxreview.2015.41 | http://taxreview.law.pitt.edu 
for a hospital to qualify as a charitable organization. The main change appears in $\S 501(\mathrm{r})$ of the Code. Hospitals on a facility-by-facility basis must meet four primary requirements: (1) establish a written financial assistance and emergency medical care policy; (2) conduct a community health needs assessment (CHNA) annually and implement a strategy to address those needs; (3) limit its charges to uninsured individuals; and (4) not engage in certain extraordinary collection actions. ${ }^{87}$ Congress also imposed a requirement on the IRS: it must audit each hospital once every three years. ${ }^{88}$

Supporting Organization Legislation: Supporting organizations are a form of charitable organization that qualifies for the favored charitable tax status of a public charity rather than as a private foundation. ${ }^{89}$ There are three types of supporting organizations, conveniently labeled Type I, Type II, and Type III..$^{90}$ When the IRS audited a number of supporting organizations in the early $2000 \mathrm{~s}$, the IRS determined that it had little concern that taxpayers were abusing the Type I and Type II supporting organization structures. The IRS believed those structures provided sufficient oversight because of substantial supervision by a supported organization. ${ }^{91}$ Of the three subjects of new rules, the supporting organization rules are the least like the other two. A supporting organization is a type of charitable organization structure rather than a line of business. Credit counseling organizations and hospitals represent a distinct line of business.

In 2006, Congress placed substantial new rules on supporting organizations. $^{92}$ It imposed restrictive rules on Type III supporting organizations and created the disfavored status of the non-functionally

\footnotetext{
${ }^{87}$ I.R.C. $\S 501(\mathrm{r})$.

${ }^{88}$ Pub. Law No. 111-148, 124 Stat. 119, § 9007(c).

${ }^{89}$ I.R.C. $\S 509(\mathrm{a})(3)$.

${ }^{90}$ I.R.C. § 1.509(a)-4(f), (g), (h), (j) (2012); see also Supporting Organizations-Requirements and Types (Feb. 11, 2015), http://www.irs.gov/Charities-\&-Non-Profits/Charitable-Organizations/ Supporting-Organizations-Requirements-and-Types.

${ }^{91}$ See, e.g., IRS Commissioner Testimony: Charitable Giving Problems and Best Practices: Hearing on Charitable Giving Problems and Best Practices Before the S. Committee on Finance, 108th Cong. (2004) (written statement of Mark W. Everson, Comm'r of Internal Revenue), available at https:// www.irs.gov/pub/irs-news/ir-04-081.pdf.

${ }^{92}$ Pension Protection Act of 2006, Pub. L. No. 109-280, §§ 1241-1245, 120 Stat. 780, 1102-1108.
}

Pitt Tax Review | ISSN 1932-1821 (print) 1932-1996 (online) DOI 10.5195/taxreview.2015.41 | http://taxreview.law.pitt.edu 


\section{2 |Pittsburgh Tax Review |Vol. 132015}

integrated Type III supporting organization. ${ }^{93}$ The legislation defined the relationships of each type of supporting organization, and directed the IRS and the Secretary of the Treasury to enact regulations directing a nonfunctionally integrated Type III supporting organization to pay a significant amount to its publically supported organization(s). ${ }^{94}$

The legislation prohibits any supporting organization from making a "grant, loan, payment of compensation, or other similar payment to a substantial contributor (or person related to the substantial contributor)." 95 The legislation prohibits the supporting organization from loaning money to any person who controls the supporting organization. ${ }^{96}$ In order to alert a supported organization about its supporting organizations, the legislation requires a supporting organization to file an annual information return and to identify all of its supported organizations. ${ }^{97}$ In addition, the statute requires a Type III supporting organization to provide notice directly to its supported organizations. ${ }^{98}$ Congress also imposed an excise tax on non-functionally integrated type III supporting organizations called the tax on excess business holdings. ${ }^{99}$ This excise tax limits the amount of stock a private foundation, and now a non-functionally integrated Type III supporting organization, can hold when that stock is also held by the donor and translates into significant control over a for-profit corporation. ${ }^{100}$ Finally, the legislation included a number of provisions that do not appear to have any particular coherence. ${ }^{101}$

${ }^{93} I d . \S 1241,120$ Stat. at 1103.

${ }^{94}$ Id.; JoInt COMm. ON TAXATION, JCX-38-06, TeChNiCAl EXPlanation OF H.R. 4, The "Pension Protection Act of 2006," As PASSED By the House On July 28, 2006, AND AS CONSIDERED BY THE SENATE ON AUG. 3, 2006 (2006). 1104.

${ }^{95}$ I.R.C. $\S 4958(c)(3)$; Pension Protection Act of 2006, Pub. L. No. 109-280, § 1242, 120 Stat. 780,

${ }^{96}$ I.R.C. $\S 4958(c)(3) ;$ Pension Protection Act $§ 1242$.

${ }^{97}$ I.R.C. $§ 6033(1)$.

${ }^{98} I d . \S 509(\mathrm{f})(1)(\mathrm{A})$.

${ }^{99} I d . \S 4943(\mathrm{f})$.

${ }^{100}$ Id. $\S 4943$.

${ }^{101}$ Congress might have in these instances legislated by anecdote rather than actual reality. That was the case with several of the private foundation rules enacted in 1969. See Thomas Troyer, The 1969 Private Foundation Law: Historical Perspective on Its Origins and Underpinnings, 27 EXEMPT ORG. TAX REV. 52 (2000).

Pitt Tax Review | ISSN 1932-1821 (print) 1932-1996 (online) DOI 10.5195/taxreview.2015.41 | http://taxreview.law.pitt.edu 
Those include: (1) Type III supporting organizations may not support foreign organizations; ${ }^{102}$ and (2) Type I and Type III supporting organizations may not receive a gift or contribution from someone who controls their supported organizations. $^{103}$

\section{E. Concluding Thoughts}

Each of these pieces of legislation is different. However, they bear significant similarities. Each takes a rule-oriented approach to a specific narrow segment of the charitable organization world. Additionally, fear of abuse of the charitable sector motivated Congress to act. Is this rule-based statutory effort by Congress for narrow segments of the charitable organization population wise or foolish?

\section{RULES V. STANDARDS LITERATURE}

This Part considers the literature regarding rules and standards. A common theme of the recent exempt organization legislation identified is that it is predominately rule-based rather than standard-based. Thus, this part considers the factors to be assessed in determining whether rules or standards are preferable.

\section{A. Rules and Standards}

"A system of rules is often thought to be the signal virtue of a system of law." "At At their best, rules eliminate the tyranny of the arbitrary acts of unelected bureaucrats against individuals they just do not like. ${ }^{105}$ Where standards reign, the argument goes, a biased agent can hide behind discretion. With true rules, discretion is circumscribed. More important, perhaps, under a legislative rule-based system, the people of the democracy choose the law they are to be governed by, rather than allowing unelected bureaucrats to

\footnotetext{
${ }^{102}$ I.R.C. $§ 509(\mathrm{f})(1)(\mathrm{B})$.

${ }^{103} I d . \S 509(\mathrm{f})(2)$. It is not at all clear why, if this requirement were appropriate, it would not also apply to Type II Supporting Organizations.

${ }^{104}$ Sunstein, supra note 5, at 968.

${ }^{105}$ Kennedy, supra note 5, at 1688.
}

Pitt Tax Review | ISSN 1932-1821 (print) 1932-1996 (online) DOI 10.5195/taxreview.2015.41 | http://taxreview.law.pitt.edu 
choose their law. Rules bring stability and certainty. They also make it easier for people to cooperate for mutual gain because they know the consequences of their actions before they act. ${ }^{106}$

However, rules are costly to enact, are not well fitted to all circumstances, and often miss their mark of an aim at justice. Furthermore, a standard arguably allows us to come closer to justice in enforcing our laws. ${ }^{107}$ A legislature that enacts a standard recognizes the limits of its ability to use language in a detailed manner to express how every situation should be governed. The standard provides flexibility to an adjudicator to achieve justice.

What is a rule and what is a standard? For purposes of this article, a rule is a legal pronouncement that allows individuals to know ex-ante whether they will violate a law. ${ }^{108}$ With a standard, the lawmaker enacts a provision that guides people in their actions, but typically the final answer is not known until after adjudication. At its simplest, a rule decides a legal matter ex-ante, while a standard decides a matter ex-post. ${ }^{109}$ This is simplistic of course. As we will see below, standards often operate in rule form. Although a standard is ostensibly in place, many still know actions that will fall inside or outside the standard. Similarly, many rules leave much room for discretion after the fact.

A classic example of the difference between a rule and a standard is a law that prohibits driving over 55 miles per hour versus a law that prohibits driving at an unsafe speed. The first is a rule, while the latter is a standard. We do not know whether we have violated the unsafe speed standard until a judge decides. Conversely, we know ex-ante whether we have violated a 55 miles per hour speed limit even before the cop stops us.

The difference between a rule and a standard is not stark. It is probably best to think of them along a continuum. Rules leave discretion to the adjudicator, and standards can apply in rule-like fashion. A policeman may exceed a 55 miles per hour speed limit. Someone driving a pregnant woman to the hospital to deliver a baby may also exceed a 55 miles per hour speed

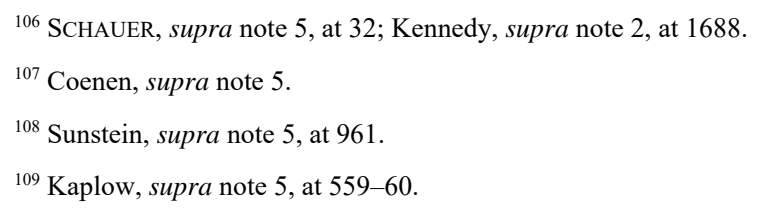

Pitt Tax Review | ISSN 1932-1821 (print) 1932-1996 (online) DOI 10.5195/taxreview.2015.41 | http://taxreview.law.pitt.edu 
limit. An adjudicator would likely apply a reasonableness exception in both instances even if a lawmaker did not detail such rules ex-ante. Thus, we see this simple rule has standard like qualities. And, as noted, standards can operate like rules. If a particular community understands that the standard prohibiting driving at an unsafe speed means that driving faster than 55 miles per hour is unsafe, then this standard operates like a rule.

\section{B. Problem of Underinclusiveness/Overinclusiveness}

It can be very difficult to develop good rules. ${ }^{110}$ The rulemaker must possess all of the current and future information needed. While finding good current information can present significant challenges, knowing or predicting the future is impossible. For instance, designing rules for information technology is particularly challenging because of its technical and rapidly changing nature. ${ }^{111}$ Rules in such an environment can quickly become anachronistic. $^{112}$

This feature of rules, the inability of the rule to consistently match the justification that led to the development of the rule, is referred to as a rule being both overinclusive and underinclusive. By overinclusive, we mean that the rule prohibits some activity that the rationale of the rule cannot justify. Thus, a requirement to drive 55 miles per hour did not take into consideration the needs of police to sometimes break that rule would be overinclusive. By underinclusive, we mean that the rule does not prohibit some activity it should prohibit. For instance, a 55 miles per hour speed limit would not stop bad drivers who do drive 55 but are unable to drive at that speed in a safe manner.

Rules tend to be transparent because they use terms that we all understand. ${ }^{113}$ However, rules are based on generalizations. ${ }^{114} \mathrm{~A}$ rule operates based on probability that a certain factual predicate will lead to a

\footnotetext{
${ }^{110}$ Lee, supra note 5; Sunstein, supra note 5, at 992.

${ }^{111}$ Lee, supra note 5.

${ }^{112}$ Sunstein, supra note 5, at 993.

${ }^{113}$ Diver, supra note 5 , at 72.

${ }^{114}$ SCHAUER, supra note 5, at 32 .
}

Pitt Tax Review | ISSN 1932-1821 (print) 1932-1996 (online) DOI 10.5195/taxreview.2015.41 | http://taxreview.law.pitt.edu 


\section{$106 \mid$ Pittsburgh Tax Review |Vol. 132015}

result that we may believe is just or not just. But, the factual predicate will be wrong in some circumstances because it is based on a generalization. This will result in not sanctioning undesirable behavior and sanctioning some desirable behavior. ${ }^{115}$ For instance, someone might prohibit dogs from entering a restaurant because they will cause problems for patrons. ${ }^{116}$ However, there might be some particularly well-trained dogs or seeing-eye dogs to which this rule should not apply. The rule would be overinclusive because it would be written to prohibit some instances where its justification does not apply. It might also be wrong in an underinclusive way by failing to prohibit activity that it should prohibit. Perhaps it fails to properly exclude unruly humans who cause similar disturbances.

Consider a rule providing that anyone over 60 years old may not be an airline pilot. ${ }^{117}$ The general point of such a rule would be to stop individuals from piloting airplanes once they have lost the ability to operate an aircraft in a safe manner. This is a very simple rule to enforce, but it may end some pilot's careers too soon, and not soon enough for others. There are efficiency losses and gains in that tradeoff.

Sometimes a simple rule that raises problems of underinclusiveness and overinclusiveness, though, can be a very effective means for a regulatory agency that is understaffed to efficiently manage its caseload. Even though the rule may not be perfect, it can be easier to administer than a standard, and can promote certainty. Overwhelmed agencies often need simple rules to make decisions quickly, efficiently, and without great cost. Conforming to this expectation, agencies with particularly crowded dockets tend to have the clearest rules. ${ }^{118}$

However, rules in this sense can also have unintended effects. If the rule is so disconnected from justice, it may be hard for the agency to enforce that

\footnotetext{
${ }^{115}$ See Kennedy, supra note 5, at 1695; Isaac Ehrlich \& Richard A. Posner, An Economic Analysis of Legal Rulemaking, 3 J. LEGAL STUD. 257, 268 (1974); Russell B. Korobkin, Behavioral Analysis and Legal Form: Rules vs. Standards Revisited, 79 OR. L. REV. 23, 36 (2000).

${ }^{116}$ See SCHAUER, supra note 5, at 32 (providing the example of the rationale behind the prohibition of dogs entering restaurants).

${ }^{117}$ Diver, supra note 5, at 69 (developing this example regarding regulating the forced retirement of airline pilots).

${ }^{118}$ Id. at 75 .
}

Pitt Tax Review | ISSN 1932-1821 (print) 1932-1996 (online) DOI 10.5195/taxreview.2015.41 | http://taxreview.law.pitt.edu 
rule. ${ }^{119}$ Under that circumstance, an agency may even explicitly choose to not enforce that law. An agency might conclude it does not have a sufficient political constituency to support that law, and avoid placing itself in a politically untenable spot. There is a strict rule that applies to charitable organizations: no inurement allowed. This is widely accepted to mean that if even one penny goes to an insider of a charitable organization, the charitable organization will lose its status. The IRS almost never enforces this rule because it seems unduly harsh. Congress enacted a rule that allows the IRS to impose a tax on less egregious forms of inurement now to try to handle this disconnect between the rule and IRS enforcement. Although not as clearly a rule, many complain today that the IRS does not sufficiently enforce political campaign activity limits on social welfare organizations. However, after the Tea Party episode, the IRS is likely afraid that it does not have the political constituency to safely enforce that rule. Thus, while there may be a rule that the IRS is supposed to enforce, it may choose not to enforce that rule because of the bad fit between the rule and the particular situation.

Professor Zelenak considers this problem. ${ }^{120} \mathrm{He}$ points out the oddity of the IRS's income treatment of frequent flyer miles earned by an employee while working for a company. While we can question whether the concept of income in the Code is a rule, many experts consider frequent flyer miles to be income for purposes of the income tax. In other words, even though the concept of income might be considered a standard, the tax community has allowed it to operate in rule form to include within its definition these frequent flyer miles earned by employees. Yet the IRS does not treat frequent flyer miles as income from an employer for enforcement purposes. ${ }^{121}$ While administratively, this might make sense, it comes with serious and obvious rule of law problems. ${ }^{122}$ Although the IRS is directed to enforce the law in a particular way, where the IRS feels uncomfortable in enforcing a rule, it

\footnotetext{
${ }^{119}$ See Sunstein, supra note 5, at 994-95.

${ }^{120}$ Lawrence Zelenak, Custom and the Rule of Law in the Administration of the Income Tax, 62 DUKE L.J. 829 (2012).

${ }^{121}$ Id. at 831; cf. Alice G. Abreu \& Richard K. Greenstein, Defining Income, 11 FLA. TAX. REV. 295, $336 \mathrm{n} .150$ (2011) (arguing that an interpretation such as what happened in the case of frequent flyer miles is not a violation of the law, but simply a practical interpretation of the meaning of income for purposes of the federal income tax).

${ }^{122}$ Zelenak, supra note 120 , at 851.
}

Pitt Tax Review | ISSN 1932-1821 (print) 1932-1996 (online) DOI 10.5195/taxreview.2015.41 | http://taxreview.law.pitt.edu 


\section{8 |Pittsburgh Tax Review |Vol. 132015}

apparently sometimes chooses not to enforce that law. ${ }^{123}$ And no one can challenge that choice.

\section{Optimal Social Welfare Analysis of a Rule or a Standard?}

Kaplow suggests a helpful way to think about whether to enact a rule or a standard. The question is whether information "should be gathered and processed before or after individual's act." 124 It is more costly to implement a rule at the legislative stage because of the informational costs. With a standard, the drafter need not anticipate all problems. Nevertheless, a standard is more costly both to individuals trying to comply, and to adjudicators interpreting that standard. In general, both the complying individual (before the act) and the adjudicator (after the act) need to seek more information under a standard than under a rule. Because of the expected extra informational cost under a standard, an individual will be less likely to comply with a standard than with the less-costly rule. The adjudicator also will need to typically spend a greater amount of time with a standard than with a rule because under the standard the judge must both determine the relevant facts and how those facts interact with the standard.

Based on the basic principle that information costs are different at different points in the rulemaking process, Kaplow builds a social welfare cost benefit model to analyze rules and standards. The model suggests that where a law will apply to many repeated acts, a rule is generally preferable. ${ }^{125}$ However, where a law will apply to only a few acts, a standard is likely preferable. ${ }^{126}$ The costs and benefits include the costs of generating information at the different stages, and the likelihood of generating a legal command that will influence citizen behavior in the most optimal manner. If an act will repeat often, legislative rules will likely reduce total costs. Additionally, citizens are more likely to inform themselves about a rule than

\footnotetext{
${ }^{123}$ In $\S 1001$, Congress defines the concept of amount realized to include money plus the fair market value of property. The IRS arguably includes in this amount realized also the value of services transferred in order to make the system work. This almost certainly was the intent of Congress, but the IRS is clearly going beyond the strict terms of the rule.

${ }^{124}$ Kaplow, supra note 5, at 585.

${ }^{125} \mathrm{Id}$. at 584-85.

${ }^{126} \mathrm{Id}$. at 585 .
}

Pitt Tax Review | ISSN 1932-1821 (print) 1932-1996 (online) DOI 10.5195/taxreview.2015.41 | http://taxreview.law.pitt.edu 
they are about a standard. Where there are few acts, it is likely more costly to develop rules for those relatively few acts. The total costs and likelihood of a small group informing themselves about the law is likely not as important as a much larger group, unless of course there is a great amount of money at stake.

For Kaplow, there is a continuum of rules and of standards that run from simple to complex. ${ }^{127}$ Kaplow contends that most analysts mistakenly compare a simple rule against a complex standard. This comparison inevitably, he argues, returns a judgment in favor of the complex standard. The simple rule is likely to be both overinclusive and underinclusive. At the same time, we all can envision how the complex standard will lead to the correct result. The simple rule typically loses to the complex standard because of concerns of justice. Kaplow asserts that this analysis is too simplistic. ${ }^{128}$ He recommends, therefore, that the analyst considering the rules standards question take into consideration the possibility of simple rules, complex rules, simple standards, and complex standards.

A simple rule is one that has few exceptions. For instance, a simple rule in the case of airline pilots might be that a pilot must retire at 60 years old. A more complex rule might employ many exceptions to a simple rule to put into rule form all of the considerations we would hope a judge might consider to get justice right for the particular circumstance. A complex rule in the airline pilot context might establish a requirement that once a pilot turns 58, he must undergo a battery of tests assessing vision, hand-eye coordination, and physical and mental fitness. A pilot could maintain his work until he became unable to pass that battery of tests. Different weight could be given to each particular factor.

A simple standard conversely might consist of only one or two factors. Such a standard would likely operate in a rule-like manner. In the pilot context, the standard might require pilots to retire when they can no longer safely fly a plane. In the case of that simple standard, it might be that all the adjudicators look at one factor: age. They might adopt a rule that at age 60 a pilot no longer has the ability to operate a plane at a high degree of safety. In this case, we would have a simple standard operating like a simple rule.

\footnotetext{
${ }^{127}$ Id. at 566 .

${ }^{128} I d$.
}

Pitt Tax Review | ISSN 1932-1821 (print) 1932-1996 (online) DOI 10.5195/taxreview.2015.41 | http://taxreview.law.pitt.edu 


\section{0 | Pittsburgh Tax Review | Vol. 132015}

Finally, a complex standard admits of many factors, none of which is determinative. In the pilot context, this might mean that the adjudicator is directed to consider the pilot's mental and physical health, dexterity, and age, along with the type of planes the pilot is flying and the conditions under which he files to determine whether the pilot can continue to fly.

This conception of the rules versus standards debate allows a more sophisticated comparison. A complex rule could be superior to a simple standard that also manages to be both underinclusive and overinclusive. Conversely, although a standard is often thought to allow the adjudicator to come closer to justice, where a standard results in inconsistent results in adjudication, a deterministic rule may very well be superior to this randomized standard. In the complex environment that charitable organizations present these guides could prove helpful in analyzing the best course to take.

While it seems to be Kaplow's sense that complex rules are generally better than complex standards, some disagree, at least within certain contexts. Professor Weisbach argues that complex rules create more complexity in certain systems and thus can be more costly overall than a complex standard. ${ }^{129}$ The intuition here is that once a rulemaker has chosen complex rules to govern a field, the rulemaker must anticipate all the ways in which those rules might be abused. The need to respond to every possible abuse in a rule-based system leads to both greater complexity and cost. This leads Weisbach to the conclusion that in the case of tax law standard-based antiabuse rules are much more economical than detailed rules. ${ }^{130}$

The drafters of the income tax often face the challenge of combatting the uncommon situation. Taxpayers regularly obtain a better tax result than the one Congress intended by modestly changing the form of a transaction. A rule-based system has to predict and handle each of those circumstances. If the law does not govern each of the uncommon circumstances, the uncommon can become common in a complex rule system. On the reasonable assumption that the uncommon situation will not occur often, adjudicators considering a complex standard only need provide the rule form for a much smaller subset of uncommon situations than would need the

\footnotetext{
${ }^{129}$ Weisbach, supra note 7 , at 862 .

${ }^{130} \mathrm{Id}$.
}

Pitt Tax Review | ISSN 1932-1821 (print) 1932-1996 (online) DOI 10.5195/taxreview.2015.41 | http://taxreview.law.pitt.edu 
legislature enacting the complex rule. ${ }^{131}$ Thus in a cost/benefit sense, the complex standard comes off as less costly. Given the complexity and uncommon nature, the complex standard likely shapes behavior as much as the complex rule. Also, in a realistic sense, the complex standard might be the only way to handle some situations because of the impossibility of knowing all the necessary information before the unusual circumstance takes place.

As rules are enacted to manage each problematic uncommon situation the complex rule system becomes more complex. A more complex system becomes in many cases easier to abuse because it is more difficult to enforce. This complexity in turn hinders efficiency. Weisbach claims that in most instances you should still want rules in tax because of the great frequency of most taxable transactions. ${ }^{132}$ However, a standard is likely a less complex way to handle the policing of the edges of a complex rule. With a standard guarding the edges, adjudicators will only have to review and decide upon perhaps ten unusual circumstances rather than the 100 that a rule-based system might spend time and cost generating. ${ }^{133}$

Weisbach believes that rules are generally the right place for most of tax law, but he believes that anti-abuse rules work quite well as standards. $\mathrm{He}$ notes that there are real costs associated with creating a complex system of rules. As rules increase, rule interactions increase at the square of the number of rules. ${ }^{134}$ Thus, as the rulemaker designs a rule-based system to anticipate every possible means of avoiding the general rule, the complexity to the system increases exponentially. In the case where there are many uncommon ways around a particular tax rule, a standard can limit the amount of rule interactions by keeping the uncommon rules to a minimum.

Despite Weisbach's cogent critique, viewing the matter of rules versus standards as a matter of gathering and disseminating information provides a useful means of assessing this age-old debate. It also opens up possibilities for analyzing a situation where rules could be made at different levels such

\footnotetext{
${ }^{131}$ Id. at 867.

${ }^{132}$ Id. at 876 .

${ }^{133}$ Id. at 872; see Adam Chodorow, Agricultural Tithing and (Flat Tax) Complexity, 68 U. PITT. L. REV. 267 (2006).

${ }^{134}$ Weisbach, supra note 7 , at 871.
}

Pitt Tax Review | ISSN 1932-1821 (print) 1932-1996 (online) DOI 10.5195/taxreview.2015.41 | http://taxreview.law.pitt.edu 


\section{2 |Pittsburgh Tax Review | Vol. 132015}

as the case of tax law where either Congress could pass rules or it could wait and allow the IRS to implement rules at the agency level.

\section{Values Approach}

Some scholars suggest there is no scientific method to determine whether rules or standards are ideal to a particular circumstance. There are simply too many factors involved. They adopt what I refer to as a valuesoriented approach that uses rules of thumb to choose between rules and standards. For instance, Professor Diver suggests that when trying to decide between a rule or a standard the rulemaker should consider three factors: transparency, accessibility, and congruency. ${ }^{135}$ While Diver is aiming in part for efficiency through these factors, he uses these factors to assess certain iconic legal environments where he indicates we should value one of those three factors more over another. Professor Sunstein also uses this values approach. He focuses on questions of democracy and circumstances under which rules or standards are more likely to be successful at achieving democracy.

Diver provides a means to judge the quality of administrative rulemaking. Does it lack specificity or is it too rigid? He uses his three factors of transparency, accessibility and congruency to consider various legal environments. By transparency Diver means law that people can understand. ${ }^{136}$ By accessibility, Diver means that the law is applicable to concrete, real-world situations. ${ }^{137}$ Finally, congruency refers to how well the law matches justification to application. ${ }^{138}$ In other words, congruency is a measure of the extent of overinclusiveness or underinclusiveness. For Diver there is no one answer to the question of whether rules or standards are better. However, he suggests that the rulemaker should evaluate these three factors to make the most informed choice. By pushing a law more toward one factor,

\footnotetext{
${ }^{135}$ Diver, supra note 5, at 67.

${ }^{136} \mathrm{Id}$.

${ }^{137} \mathrm{Id}$.

${ }^{138} I d$.
}

Pitt Tax Review | ISSN 1932-1821 (print) 1932-1996 (online) DOI 10.5195/taxreview.2015.41 | http://taxreview.law.pitt.edu 
the rule maker will typically be pushing the rule away from the other two factors. ${ }^{139}$

Diver provides rules of thumb for situations rules might be superior to standards or vice versa. For instance, he suggests that on the one hand, internal agency law is typically served better by standards. ${ }^{140}$ Congruence tends to be highly important in running an agency - the agency wants to ensure its resources are being utilized wisely. ${ }^{141}$ On the other hand, external rules that the agency administers are more likely to be aided by being stated in rule form ${ }^{142}$ where factors of transparency and accessibility are likely to be more important. As an example, Diver suggests that the proper allocation of agency resources can be a real challenge; thus, rough standards will likely serve the agency administrators better than explicit rules in allocating those scarce resources. ${ }^{143}$ However, courts typically require external rules regarding investigative functions to be more transparent. ${ }^{144}$

He also compares sanctioning rules with liability rules. ${ }^{145}$ There, Diver finds that punishment tends to be less transparent, while criminal rules tend to be more precise. ${ }^{146}$ Compliance tends to be particularly important in law regarding liability for acts. Thus, rulemakers should strive for transparency in crafting laws regarding liability in order to obtain greater levels of compliance. The rulemaker crafting sanctioning rules, however, is trying to accomplish many different goals such as punishing in a manner measured to the crime and deterrence. ${ }^{147}$ These different goals make achieving

\footnotetext{
${ }^{139}$ Id. at 70.

${ }^{140} \mathrm{Id}$. at 76 .

${ }^{141} I d$.

${ }^{142} I d$.

${ }^{143} \mathrm{Id}$.

${ }^{144}$ Id. at 77 .

${ }^{145} \mathrm{Id}$.

${ }^{146}$ Id. at 78.

${ }^{147}$ Id.
}

Pitt Tax Review | ISSN 1932-1821 (print) 1932-1996 (online) DOI 10.5195/taxreview.2015.41 | http://taxreview.law.pitt.edu 


\section{4 | Pittsburgh Tax Review | Vol. 132015}

transparency quite tough. ${ }^{148}$ Congruence is likely a more important goal in these situations.

Finally, Diver compares licensure schemes with prohibitory rules. ${ }^{149}$ This final comparison is probably the most useful analogue to charitable organization oversight because the primary activity of the IRS is a licensing system. Diver argues that licensing systems are typically highly complex in nature and less susceptible to the use of rules. ${ }^{150}$ While direct prohibitions or commands can typically be stated in clear, transparent language, licensing systems must provide a broad sense of permission based on a large number of undefined complex factors; they are thus more difficult to express as rules. ${ }^{151}$ Based on the fact that excluding someone from a licensing scheme typically comes with large costs to the loser, Diver comes down in favor of aiming for congruency, and therefore standards, in most of these regimes. ${ }^{152}$ However, in the situation where there is small cost lost and a large volume of cases, he is more inclined to give up a bit on congruence and go more for transparency and accessibility. ${ }^{153}$

Professor Sunstein also employs a values oriented approach. ${ }^{154}$ To Sunstein, the debate pits congruence with ideal law against unfettered discretion to unelected judges and bureaucrats. ${ }^{155}$ Sunstein examines the values that rules promote: equal treatment, minimal informational costs of decisions, and predictability for private actors. He also considers the main arguments against rules such as that they are both overinclusive and underinclusive, they can actually mask bias, and they allow evasion by wrongdoers.

\footnotetext{
${ }^{148} I d$.

${ }^{149}$ Id. at 79 .

${ }^{150} I d$.

${ }^{151} I d$.

${ }^{152} I d$.

${ }^{153} \mathrm{Id}$.

${ }^{154}$ Sunstein, supra note 5.

${ }^{155}$ Id. at $957-58$.
}

Pitt Tax Review | ISSN 1932-1821 (print) 1932-1996 (online) DOI 10.5195/taxreview.2015.41 | http://taxreview.law.pitt.edu 
Sunstein's primary goal is to resurrect, in a sense, case-by-case justice to show that rule of law goals can be met by some relaxation of a requirement for rules. ${ }^{156}$ Sunstein builds his case for modestly straying from a rule-based system on the premise that people in a democracy should have a right to particularistic judgment of their particular case. ${ }^{157}$ He argues that we have a tradition in our legal system of allowing legitimate rule revisions and that this tradition is quite democratic. ${ }^{158}$ Embracing that tradition in proper places can be democratic enhancing rather than harming.

Finally, like Diver, Sunstein encourages a close look at the circumstances in which laws are being erected. ${ }^{159}$ Different contexts demand different types of legal structures. He believes that it is possible to size up different matters and get a sense of whether rules or standards are generally going to be preferable. Sunstein looks at many of the same factors that Diver and Kaplow and others considered. At the end, he notes that there can be no rule that makes the determination, but it must be a question of factors that we consider. Those include: "the likelihood of bias, the extent of current information, the location and nature of social disagreement, the stakes, the risk of overinclusiveness, the quality of those who apply the law, the alignment or nonalignment of views between lawmakers and others, the sheer number of cases." 160

\section{RULES OR STANDARDS FOR CHARITABLE TAX LAW?}

Requiring an organization to operate for a "charitable purpose" is obviously a standard. But, perhaps more importantly, this is a standard that is quite difficult to make into a rule. There likely is no set of optimal rules for determining which organizations should be granted charitable tax-exempt status. It is also highly unlikely that some ideal notion exists in the law implemented by Congress. Further, as discussed above, the nature of "charitable" is a concept that changes over time because it depends on the

\footnotetext{
${ }^{156} I d$.

${ }^{157}$ Id. at 958.

${ }^{158}$ Id. at 1008 .

${ }^{159}$ Id. at 1012 .

${ }^{160}$ Id. at 1016.
}

Pitt Tax Review | ISSN 1932-1821 (print) 1932-1996 (online) DOI 10.5195/taxreview.2015.41 | http://taxreview.law.pitt.edu 


\section{6 | Pittsburgh Tax Review | Vol. 132015}

moral proclivity of society today along with its needs. ${ }^{161}$ In light of these challenges, is it possible to develop good rules to govern charitable organizations in the tax realm? Even if it is difficult, might there be reasons of stability and certainty and efficiency to provide imperfect rules? Furthermore, if rules are desired, in what situation are they desired, and who is the best institutional player to draft those rules?

The first part reviews a couple of recent attempts to determine whether rules or standards are more appropriate for one part of the tax-exempt law: political activity prohibitions. It next turns to the reality that it is difficult to write rules regarding charitable organizations because of the complexity of that regime. Section $\mathrm{C}$ applies both the Kaplow analysis and the values approach to examine the charitable tax-exempt organization legal environment. Section D considers who should develop the rules and what form those rules should take.

\section{A. Former Rules/Standards Analyses Applied to the Charitable Sector}

Two scholars recently each provided assessments of the rules and standards debate as it applies to a narrow rule in the charitable and social welfare tax-exempt organization's context. ${ }^{162}$ Professor Aprill reviewed the rule that prohibits a charitable organization from intervening in a political campaign, and Professor Mueller reviewed the very similar rule in the social welfare organization context. Because this law presents many of the challenges that charitable organization tax law presents generally, this section reviews their analyses first. Do they have broader implications for the charitable sector?

Aprill uses Kaplow's optimal analysis to assess whether rules or standards are better to implement the prohibition on political campaign

${ }^{161}$ E.g., Bob Jones Univ. v. United States, 461 U.S. 574 (1983) (stating that although schools that discriminated on the basis of race were clearly charitable under the Code when the initial Internal Revenue laws were established, because of changing societal public policy, that was no longer the case by the 1970s).

${ }^{162}$ Ellen Aprill, Why the IRS Should Want to Develop Rules on Charities and Politics, 62 CASE W. RES. L. REV. 643, 647 (2012); Jennifer Mueller, Defending Nuance in an Era of Tea Party Politics: An Argument for the Continued Use of Standards to Evaluate the Campaign Activities of 501(c)(4) Organizations, 22 GEO. MASON L. REV. 103 (2014).

Pitt Tax Review | ISSN 1932-1821 (print) 1932-1996 (online) DOI 10.5195/taxreview.2015.41 | http://taxreview.law.pitt.edu 
intervention. ${ }^{163}$ Because there is a very low level of enforcement of this prohibition, standards would normally be best under the Kaplow analysis. However, there is a competing value involved. Where many are subject to a command and there is low enforcement, rules may be best. Rules can ensure the desired norm is understood and followed. Furthermore, where the groups that are subject to the command are small, unsophisticated organizations, as is the case with the vast majority of the charitable sector, there might be a real need for simple rules because these can be easier for the unsophisticated to seek out, understand, and follow. ${ }^{164}$

Aprill notes that there is no agreed-upon norm regarding whether or what political campaign intervention should be restricted; this makes it difficult to draft rules. ${ }^{165}$ For instance, some believe a charity's political speech should be restricted to maintain tax-exempt status; others believe the First Amendment protects a charitable organization's right to engage in all political speech. ${ }^{166}$ Aprill argues that this lack of a norm actually augurs in favor of rules. ${ }^{167}$ Rules could help both legislators and organizations move closer to a legal norm and provide greater stability where instability currently lies. It is likely that some organizations engage in more political speech than they should and that some organizations engage in less than they could. This creates inefficiency, and rules could work to limit these harms Aprill contends. ${ }^{168}$

Aprill recognizes Weisbach's concern that aggressive taxpayers can and do abuse tax rules and that under certain circumstances adopting rules to manage these problems can make the tax system more costly. ${ }^{169}$ Aprill finds though that the anti-abuse concerns typical to tax law are not prevalent in

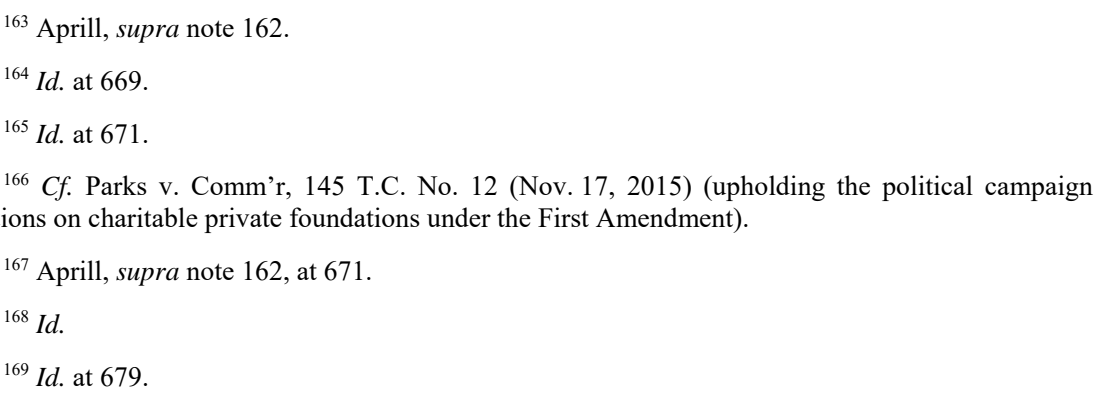

Pitt Tax Review | ISSN 1932-1821 (print) 1932-1996 (online) DOI 10.5195/taxreview.2015.41 | http://taxreview.law.pitt.edu 


\section{8 |Pittsburgh Tax Review | Vol. 132015}

political campaign intervention; thus, standards are not to be favored here for anti-abuse reasons. ${ }^{170}$

In the end, Aprill finds that the factors weigh in favor of a more robust rule-based regime. ${ }^{171}$ Of particular importance is that many unsophisticated taxpayers are trying to abide by important rules that implicate free speech. In this circumstance, rules can bring about more compliant behavior and likely lead to more equitable treatment to all taxpayers.

Professor Mueller reviews a similar set of laws related to political speech prohibitions in the context of $\S 501(\mathrm{c})(4)$ social welfare organizations. ${ }^{172}$ While exempt from federal income tax, contributors may not deduct contributions to social welfare organizations as charitable contributions. ${ }^{173}$ Although presented with a related law, Mueller comes to the exact opposite conclusion of Aprill. She argues that given the complexity of the regime, only standards really make sense. Mueller also believes the great possibility for circumvention in this area militates for a standard based regime. ${ }^{174}$ In particular, she marshals evidence that uncertainty can actually increase compliance rather than decrease it. ${ }^{175}$ Furthermore, Mueller notes that low enforcement of the command and misalignment of the penalty for violating the campaign prohibition pushes towards a conclusion that standards are better here. ${ }^{176}$ Finally, looking at the challenges that the FEC faces in enforcement of election laws even with rules, Mueller argues that the political challenge of passing rules that will not generate new enforcement costs are too great. ${ }^{177}$ Enforcement costs will continue whether there are rules or not.

\footnotetext{
${ }^{170} \mathrm{Id}$. at 678.

${ }^{171} I d$. at 680 .

${ }^{172}$ Mueller, supra note 162.

${ }^{173}$ I.R.C. § 501(c)(4); cf. id. § 170.

${ }^{174}$ Mueller, supra note 162, at 133.

${ }^{175}$ Id. at 135 .

${ }^{176} \mathrm{Id}$.

${ }^{177}$ Id. at $143-55$.
}

Pitt Tax Review | ISSN 1932-1821 (print) 1932-1996 (online) DOI 10.5195/taxreview.2015.41 | http://taxreview.law.pitt.edu 
Thus, in assessing one small part of the current standard-based regime regarding charitable or social welfare organizations, we see conflicting opinion on whether rules or standards are better. Of course, that makes sense regarding politics, an issue that brings a significant difference of opinion. Is it any different when we turn to the basic rules of being a charitable organization?

\section{B. Challenges in Rulifying the Charitable Norm}

Why might the concept of a charitable organization be so hard to nail down in a satisfying, stable manner? First, the concept of a charitable organization has multiple rationales and it changes over time because of changes in society and technology. ${ }^{178}$ This makes settling on the rules at the legislative stage difficult and costly. Secondly, the idea of a charitable organization is applied to the concept of organization. Not only is there a quantifying aspect relative to acts and time, there is an attribution complexity. ${ }^{179}$ Finally, there is the difficulty that almost any type of activity, whether it be surfing or cooking or manufacturing, can be accomplished in a charitable manner. This final point means that the permutations of possible charitable organizations are likely infinite.

As discussed in Part II.A, there are likely a number of congressional rationales for the charitable tax-exempt regime. It may: (1) provide a subsidy for organizations that provide an equivalent public benefit, (2) regulate charitable organizations, and (3) enhance pluralism. These different purposes, almost certainly point in different directions at times. A legislator or an adjudicator may find himself confused as to which purpose to place first or even primary. Additionally, if charitable tax law is intended to support the value of pluralism, it is likely that only a standard can accomplish this goal. Pluralism is an idea that suggests our government works best when

\footnotetext{
${ }^{178}$ There is certainly a laymen's conception of charity that it is aid to the poor alone. However, that is definitely not consistent with the conception Congress adopted or that the IRS implements or with the idea of charitable within the charitable trust law context.

${ }^{179}$ See, e.g., Presbyterian \& Reformed Pub. Co. v. Comm'r, 743 F.2d 148, 155 (3d Cir. 1984) (noting the great difficulty of determining intent of a party, but the even greater challenge with determining intent with respect to a corporation). Admittedly, the problem of attribution is faced in any legal system that must deal with legal entities.
}

Pitt Tax Review | ISSN 1932-1821 (print) 1932-1996 (online) DOI 10.5195/taxreview.2015.41 | http://taxreview.law.pitt.edu 
groups promote all the different interests in our society. It suggests that we as a country should value diversity. As Justice Powell suggested in Bob Jones University, we should be hesitant to create a charitable tax law to enforce the status quo. ${ }^{180}$ Charitable tax law should instead promote a range of diverse ideas. If we want to promote new ideas, a rule-oriented regime is quite likely to restrict those new ideas before they even arise.

The fact that there are at least three purposes to the law can lead to different directions for the rules. Some laws might be designed to identify organizations that should not pay tax, while others might be more focused on regulating charitable organizations. For instance, the recent legislation on credit counseling and hospitals discussed in this Article seems to be motivated largely by the second purpose rather than the first. In this legislation, Congress is interested in regulating the charitable sector rather than in directly determining organizations that are worthy of tax exemption or not. Some of these provisions might have looked different if the tax base were the only consideration.

Additionally, concepts subject to great social variability are difficult to turn into rules. For example, the concept of obscenity is commonly understood to be nearly impossible to express with clarity; instead, we know it when we see it. ${ }^{181}$ Part of the difficulty of expression is that it changes over time with changes in culture and community. This means that a standard may be required to solve such a legal problem. The concept of "charitable" is quite similar. While it is a broad, expansive notion with deep history rooted in English law, ${ }^{182}$ it is based in community notions of what is good. The meaning of charitable purpose thus changes with some regularity. ${ }^{183}$

\footnotetext{
${ }^{180}$ Bob Jones Univ. v. United States, 461 U.S. 574, 606 (1983) (Powell, J., concurring).

${ }^{181}$ Jacobellis v. Ohio, 378 U.S. 184, 197 (1964) (Justice Stewart stating: "I shall not today attempt further to define the kinds of material I understand to be embraced within that shorthand description ['hard-core pornography']; and perhaps I could never succeed in intelligibly doing so. But I know it when I see it, and the motion picture involved in this case is not that.").

182 See Preamble to the Statute of Charitable Uses, 43 Eliz. ch. 4 (1601); Bob Jones Univ. v. United States, 461 U.S. 574, 588-89 (1983) (discussing long history of the idea of charitable purpose).

${ }^{183}$ The IRS at one time did not accept that joint ventures were possible between a charitable organization and a for profit organization. But today, it fully accepts them. See Rev. Rul. 98-15, 1998-1 C.B. 718. Donor Advised Funds were also generally prohibited, but today Congress has implemented a regime to fully accept them. Although in both instances the IRS was forced into these positions by courts
}

Pitt Tax Review | ISSN 1932-1821 (print) 1932-1996 (online) DOI 10.5195/taxreview.2015.41 | http://taxreview.law.pitt.edu 
In Bob Jones University v. Commissioner, the Supreme Court explicitly recognized the changing nature of the charitable standard. ${ }^{184}$ Although discrimination on the basis of race was widely accepted by Congress in 1913 when the Income Tax was enacted, the Court held that discrimination on that basis now violated a fundamental public policy. ${ }^{185}$ This example illustrates how society can change its mind regarding the nature of a charitable purpose.

Many changes in charitable purpose take place as a result of changes in technology, law, and society. For instance, the changes in the activities and the character of hospitals from the start of tax-exemption in 1913 (when there were mostly almshouses to serve as hospitals) ${ }^{186}$ to today (when gigantic health systems with large insurance components roam the United States) are dramatic. ${ }^{187}$ Even the hospitals that qualified in 1969 look quite different than they do today in 2015. ${ }^{188}$ The development of Medicare and Medicaid and the significant changes in health care law and financing played a large role in those dramatic changes. In that time, the IRS has had to assess the charitable nature of many different models of healthcare delivery. ${ }^{189}$

These changes are found throughout the charitable sector. As one Treasury Department research paper noted, "[o]ne reason that there have been few attempts to provide a comprehensive definition [of charity] is that

and Congress, these do still arguably reflect a change in societal views. The IRS certainly is not the definer of social norms, but only an interpreter in attempting to oversee charitable tax-exempt law.

${ }^{184}$ Bob Jones Univ. v. United States, 461 U.S. 574 (1983).

185 Id.

${ }^{186}$ Mark A. Hall \& John D. Colombo, The Charitable Status of Nonprofit Hospitals: Toward a Donative Theory of Tax Exemption, 66 WASH. L. REV. 307, 318 (1991).

${ }^{187}$ See IHC Health Plans, Inc. v. Comm'r, 325 F.3d 1188 (10th Cir. 2003).

${ }^{188}$ Compare the prototypical hospitals considered in Rev. Rul. 69-545 with the complex system reviewed in IHC Health Plans, Inc. v. Comm'r, 325 F.3d 1188. On the one hand, the standard to consider these cases was the same, but on the other, the financial and management complexity considered in IHC health systems was vastly different than the brick and mortar hospital considered in 1969. See also JAMES J. FISHMAN ET AL., TAXATION OF NONPROFIT ORGANIZATIONS 84 (4th ed. 2015) (discussing the change in the IRS position from a relief of poverty rationale to a community benefit standard).

${ }^{189}$ For example, most recently the IRS had to determine how to treat Regional Health Information Organizations that maintain electronic health care records for a large region: Regional Health Information Organization (RHIO) Frequently Asked Questions, INTERNAL REVENUE SERV. (Jan. 8, 2015), http:// www.irs.gov/Charities-\&-Non-Profits/Charitable-Organizations/Regional-Health-InformationOrganization-(RHIO)-Frequently-Asked-Questions.

Pitt Tax Review | ISSN 1932-1821 (print) 1932-1996 (online) DOI 10.5195/taxreview.2015.41 | http://taxreview.law.pitt.edu 


\section{2 |Pittsburgh Tax Review | Vol. 132015}

charitable activity constantly changes, and formulating a definition is extremely difficult when the object to be defined is in flux." 190 While some things stay the same, such as pure assistance to the poor, or most full-time schools, there are real changes in types of organizations that the IRS reviews today from what it reviewed in the past. Few newspapers sought charitable status in the past. However, today, newspapers are more and more considering the charitable model as a possible solution to the difficulties of the news market. ${ }^{191}$ Law schools might also begin using the charitable model to develop a new legal training model inside a training law firm. ${ }^{192}$

Whether, our social notion of charitable changed on each of these matters, or it changed to accommodate technical change, does not matter. Also, whether society changed its mind, or the IRS implemented new guidance creating that change, does not matter. Because of value and technical change, our notion of charitable in healthcare provision is quite different today than it was back in the 1950s. This change makes it difficult to write legislative rules that cover the legislative intent on ideal charitable law. Rules can be written of course, but they are likely to miss many important differences in social value change, and technological and organizational change.

The application of the charitable purpose standard to an organization is highly complex too. Section 501(c)(3) seems to imply that whether an organization qualifies depends on every act of the organization during any particular taxable year. The standard of "organized and operated exclusively for a" charitable purpose strongly suggests this; furthermore, the idea of a charitable purpose implies such an all-encompassing notion as well. For instance, in Revenue Ruling 69-545, the IRS was called on to determine whether Hospital A was operated for a charitable purpose. The IRS considered all of the contracts of the hospital, all of the acts of people who governed the organization, and generally considered the complete operation

\footnotetext{
${ }^{190}$ Persons et al., supra note 40, at 1943.

${ }^{191}$ See Richard Schmalbeck, Financing the American Newspaper in the Twenty-First Century, 35 VT. L. REV. 251 (2010).

${ }^{192}$ See Adam Chodorow \& Philip T. Hackney, Post-Graduate Legal Training, 65 J. LEGAL EdUC. (forthcoming 2016).
}

Pitt Tax Review | ISSN 1932-1821 (print) 1932-1996 (online) DOI 10.5195/taxreview.2015.41 | http://taxreview.law.pitt.edu 
of the hospital in all of its facets from the emergency room to the operation of its laundry. It did this because the law demands such an analysis.

If the law required an organization to "operate exclusively for an exempt purpose," any one bad fact could take an organization out of charitable status. Such an interpretation could have been a time saver for the IRS. However, the IRS interpreted that requirement to mean that an organization qualifies if it "primarily engages in activities," that accomplish such an exempt purpose. ${ }^{193}$ This means, in a practical sense, that the IRS must review almost every act of the organization during the year so that it can quantify whether the organization is organized and operated primarily for a charitable purpose. Any charitable tax rule needs to take into consideration this significantly factually complex environment.

Also, challenging is the need for the IRS to attribute actions of employees and volunteers to the nonprofit entity. To determine the acts of a nonprofit entity, the IRS must evaluate who acts for the entity. ${ }^{194}$ The difficulty of this challenge can be seen in the IRS's attempt to review whether All Saints Episcopal Church might have violated the prohibition on intervention in a political campaign. In that case, a visiting minister spoke before the church and arguably advocated for the election of John Kerry and against the election of George Bush in the 2004 presidential election. ${ }^{195}$ The question was whether a visiting minister could be considered to be acting on behalf of the church when he spoke before the group, such that his advocacy could be considered prohibited political intervention on the part of the church. This same matter is seen again and again in much more mundane situations. This extra layer makes rulemaking again subject to more complexity in charitable tax law.

Admittedly, anyone reviewing the acts of an entity for legal purposes is presented with the same problem. However, in the realm of tax, I contend that this factor is exacerbated a bit more in the charitable organization context

${ }^{193}$ Treas. Reg. § 1.501(c)(3)-1(c) (as amended in 2014) (italics added).

${ }^{194}$ See, e.g., Rev. Rul. 2007-41, 2007-4 C.B. 1421 (in situations 3-6, the IRS examines whether charitable organization leaders are acting in their own capacity or as capacity of the leader of an organization for purposes of political activity).

${ }^{195}$ Rebecca Trounson, IRS Ends Church Probe but Stirs New Questions, L.A. TIMES, Sept. 24, 2007, http://articles.latimes.com/2007/sep/24/local/me-allsaints24.

Pitt Tax Review | ISSN 1932-1821 (print) 1932-1996 (online) DOI 10.5195/taxreview.2015.41 | http://taxreview.law.pitt.edu 
because of the overwhelmingly subjective nature of the judgment regarding the acts that must be made.

Ultimately, determining whether an organization is charitable is a different activity than determining whether a single transaction is taxable. This problem is the same as that identified by Diver regarding the difference between creating prohibitory rules and license systems. ${ }^{196}$ The latter are necessarily more complex and much harder to turn into rules. The point is that whether any organization is charitable is likely to be sui generis. This means that obtaining our ideal rule will be very costly because it is highly complex.

A legislature could try to solve this second challenge through rules that require certain quantities of money or work-time to be dedicated to some narrowly defined activities that the legislature deems to be charitable. Congress has tried this solution in part with respect to private foundations. ${ }^{197}$ These charitable organizations are required to meet a highly complex payout requirement that only those with sophisticated tax counsel should attempt. ${ }^{198}$ Although the system does not define charitable acts, it does define the quantity of acts an organization must perform during the year to be considered charitable. In other words, the private foundation rules are a solution in part to the second problematic issue identified in this section. However, this regime is so complex that most organizations cannot afford the costs of complying with the rules.

Now the close reader might be saying, "He can't be arguing that taxexempt charitable law is so complex that it is more complex than the tax law itself. If that were the case, then Congress should simply erect standards throughout the Code. Surely, you don't intend to make that argument?" First, it is perfectly legitimate and in fact advisable for Congress to enact rules in the Code. However, why argue that for the Code generally, but not so much

\footnotetext{
${ }^{196}$ See supra Part III.D.

${ }^{197}$ See, e.g., I.R.C. $\S \S 4940-4946$.

${ }^{198}$ Id. $\S$ 4941-4942. Consider that Mark and Chan Zuckerberg recently eschewed the private foundation model even though they are planning to donate a reported $\$ 45$ billion in Facebook stock. Many have suggested that the reason that they might avoid private foundation rules is that they are too costly, restrictive, and complex. Kerry Dolan, Mark Zuckerberg Explains Why the Chan Zuckerberg Initiative Isn't a Charitable Foundation, ForBES (Dec. 4, 2015), available at http://www.forbes.com/sites/ kerryadolan/2015/12/04/mark-zuckerberg-explains-why-the-chan-zuckerberg-initiative-isnt-a-
} charitable-foundation/.

Pitt Tax Review | ISSN 1932-1821 (print) 1932-1996 (online) DOI 10.5195/taxreview.2015.41 | http://taxreview.law.pitt.edu 
when it comes to charitable organizations? The answer to that question is that most Code provisions are focused on single transactions that can be looked at numerically and as simple discrete acts.

For instance, basic income tax principles focus on single transactions at a time and the question is typically whether a particular expense is deductible or a particular gain is income. Even in corporate tax, which presents much in the way of complexity, the fundamental matter at issue is a final taxable amount. That taxable amount is generated based on thousands of individual transactions of basic income tax. Each of those transactions is valued and placed into a minus category, a plus category, or a nothing category. The charitable organization presents a similar number of economic transactions, but individual acts that have no value in any economic sense must be considered as well. And more importantly, although we might envision the calculus as to each act a question of charitable or not charitable, that calculus is a more complex social analysis that likely resembles all of the space between zero and one rather than simply a question of zero and one.

Of course, there are places in the Code where a similar organizational complexity must be addressed. Partnership taxation comes immediately to mind. As in the charitable organization area, Congress tends to enact standards in partnership tax that the IRS must implement by enacting complex rules. Other matters that call for standards include issues of debt vs. equity, economic substance, and the question of whether a transaction was arm's length or not. Those matters are typically dispensed with on a case-bycase basis rather than on the basis of rules established beforehand. This is likely the place where we end up for a very important reason-predicting all the possible ways the law might interact with complex reality is impossible in these realms and standards simply must govern these worlds.

Finally, the charitable tax-exempt regime applies to an infinite slice of life. We can find a way to make any sector of our economy charitable. Health care, insurance, education, grocery stores, the practice of law, the provision of housing, the provision of credit, the selling of cars, skateboarding, the operation of a radio, and on and on all can be considered charitable activities if the organization is established and operates properly. Trying to find simple rules, or even complex ones, to apply to such complexity is likely an impossible challenge.

Pitt Tax Review | ISSN 1932-1821 (print) 1932-1996 (online) DOI 10.5195/taxreview.2015.41 | http://taxreview.law.pitt.edu 


\section{6 |Pittsburgh Tax Review | Vol. 132015}

\section{Optimal Kaplow Analysis/Values-Oriented Approach}

Using Kaplow's analysis, we first assess how often the act to be governed by a rule or a standard is repeated. If an act is repeated often, a rule is likely preferable. Thus, to do the analysis we need to know what act we should focus upon.

There is generally no one particular act for charitable organizations. The most common act, if it can be called that, is for an organization to operate primarily for a charitable purpose during a taxable year. The most common place where the IRS considers this question is when the IRS reviews a charitable organization's application for recognition as a charitable organization. It considers this same question when it reviews a charitable organization on audit. There are some prescriptive rules, such as a complete ban on inurement or intervention in a political campaign, that often consist of a simple act. However, even these matters typically assist in the charitable purpose analysis. For simplicity, the analysis will focus primarily on the charitable purpose analysis.

As discussed in Part II.C, there are a lot of organizations that must demonstrate compliance with the charitable tax-exempt regime annually. According to IRS statistics, there are around 1.2 million charitable organizations. ${ }^{199}$ The IRS data, however, is not complete. There are more charities than represented in data because this number does not include much of the church community or small organizations. ${ }^{200}$ Additionally, the IRS receives around 70,000 applications per year. ${ }^{201}$ In any case, the number of charitable organizations is relatively large. This would suggest rules might be preferable.

The above numbers, however, may misrepresent the total number of charitable organizations where rules are needed. The charitable standard

\footnotetext{
${ }^{199}$ See McKeever \& Pettijohn, supra note 64.

${ }^{200}$ Under $\S 508(\mathrm{c})$ small organizations and churches need not file an application to be recognized as a charitable organization.

201 Questions and Answers on 501(c) Organizations (May 15, 2013), http://www.irs.gov/ uac/Newsroom/Questions-and-Answers-on-501\%28c\%29-Organizations [hereinafter Questions and Answers] (noting the number of applications received); see also INTERNAL REVENUE SERV., supra note 81 (noting the number of applications received).
}

Pitt Tax Review | ISSN 1932-1821 (print) 1932-1996 (online) DOI 10.5195/taxreview.2015.41 | http://taxreview.law.pitt.edu 
arguably works like a simple rule for a large percentage of the charitable sector. A lot of charitable organizations do perfectly charitable things, such as assisting the needy, educating children, or delivering meals to old people. ${ }^{202}$ These likely are some of the most frequent applicants for charitable status. If we were able to winnow out these organizations from the count of acts, the total number of organizations is reduced. Yet, we are still probably left with a significant number of organizations for which more detailed rules could be useful.

Nevertheless, the question at hand regarding acts is how often the same act occurs. When we look at it in this way, we find that the act is not repeated as often as an organization count alone would suggest. As argued above, almost every charitable organization is charitable in its own way. We have booster clubs, schools, colleges, technical training, insurance companies, health care organizations, credit counseling organizations, pet rescue operations, research institutes, boy scouts, churches, many forms of poverty relief, housing, old age ... the list goes on and on. And, within each of those contexts there is great diversity too. The means to educate in a charitable manner are endless, as are the means to supply housing, religion and every other activity charities engage in. This factor of intense organizational diversity strongly supports standards. There are few places where rule development at a legislative level is simple because the "act" is so complex. Generating information before the "act" is quite difficult. It is better from an economic sense and an inclusive sense to develop the rule after the act.

However, there are parts of charitable tax law that do repeat, and there are instances of discrete acts. For example, inurement and political intervention typically consist of relatively discrete acts. Where such discrete acts can be identified, the repeat of the act will be often, the rule to govern can be of a more simple variety, and unsophisticated parties are more likely to be able to comply. Professor Aprill is therefore probably right that a simple rule-based regime would be useful in the political speech context. There are specific acts that make rules easier to develop. Those rules could lead to a higher degree of compliance particularly among smaller, less sophisticated charities that would be able to access such simple rules with greater ease.

\footnotetext{
${ }^{202}$ But cf. Mayer, supra note 4, at 16 (arguing that it is not clear whether compliance is high or low because the IRS simply is not looking at enough organizations for us to know).
}

Pitt Tax Review | ISSN 1932-1821 (print) 1932-1996 (online) DOI 10.5195/taxreview.2015.41 | http://taxreview.law.pitt.edu 
Troublingly though, it may be impossible to enact rules in the political activities arena because of the necessarily high political costs to such rulemaking. ${ }^{203}$

The analysis however does not stop at the frequency of the act. For Kaplow, we must take into consideration the sophistication of the parties, the money involved, and whether rules, even if complex, may generate more right answers than a standard.

If there are unsophisticated parties, rules might generate a greater degree of compliance. Unsophisticated parties with little money are unlikely to seek guidance on the law where it appears that the cost of determining it will outweigh any gain they might achieve from seeking legal advice. If there are sophisticated parties and lots of money involved, even if there are only a small number, it may make sense to invest time in making good rules before the act.

As developed in Part II.C there are likely many unsophisticated nonprofit organizations - perhaps $70 \%$ to $80 \%$ of the field. This factor would point in the direction of developing rules to obtain greater compliance with the law. However, those rules likely need to be simple to provide a benefit to unsophisticated parties because complex rules are likely to dissuade unsophisticated parties from seeking legal advice. This may be a problem for rules for charitable organizations. For the reasons discussed above regarding the diversity of charitable organizations, the rules needed are likely to be highly complex in this way. Additionally as rule interactions increase, the complexity of charitable tax law is likely to become truly formidable. Thus, in the case of charitable purpose, although there may be some desire for rules

\footnotetext{
${ }^{203}$ The IRS arguably tried to do just this in promulgating new rules to apply to the political activities of social welfare organizations. See I.R.S. News Release, IR-2013-92 (Nov. 26, 2013). The notice was posted on the Federal Register on November 29, 2013 as a Notice of Public Rulemaking (NPRM). Guidance for Tax-Exempt Social Welfare Organizations on Candidate-Related Political Activities, 78 Fed. Reg. 71,535 (proposed Nov. 29, 2013) (to be codified at 26 C.F.R. pt. 1). In that NPRM the IRS proposed a rule-based regime. For instance, it explicitly defined voter guides as candidate-related political activity in Prop. Treas. Reg. $\$ 1.504-1(\mathrm{a})(2)($ iii)(7). Id. Previously, whether a voter guide was not an exempt activity was determined on a standard that considered all the facts and circumstances. See, e.g., Rev. Rul. 2007-41, 2007-1 C.B. 1421. Although some provided support for the NPRM, the loudest voices strongly criticized the new rules. See, e.g., Deirdre Shesgreen, IRS Proposal on Non-profit Political Activity Criticized, USA TODAY, Feb. 26, 2014, http://www.usatoday.com/story/news/politics/2014/02/ 26/irs-non-profit-rules/5846445/.
}

Pitt Tax Review | ISSN 1932-1821 (print) 1932-1996 (online)

DOI 10.5195/taxreview.2015.41 | http://taxreview.law.pitt.edu 
to increase compliance among unsophisticated parties, we may not be able accomplish that goal.

There are also sophisticated wealthy organizations such as hospitals, universities, and foundations. It is possible that spending some significant up-front time to generate good rules for these organizations could be useful. These rules would likely need to be complex if we want to avoid significant under and over inclusion. Thus, developing them is very costly, and may be impossible because of the change that takes place in these sectors. Also, highly complex rules in this area might harm the large unsophisticated sector because these rules are likely to interact with the rules that impact the unsophisticated parties. That additional complexity again is likely to deter unsophisticated party compliance.

Finally, in the enforcement context, rules can help enforcers manage where there are many acts to be reviewed and agency resources are low. IRS resources are inadequate to oversee the charitable organization sector. This factor weighs in favor of developing rules to help the IRS manage its workload. Consistent enforcement of the law with rules may be better than sporadic inconsistent enforcement of a standard. Of all the factors, this one weighs the most strongly in favor of rules.

This analysis leaves us with conflicting guidance. Many of the factors suggest that at the level of charitable purpose we would be best served to leave the legal command at the level of standards. The complexity and changing nature of charitable purpose make rules likely to be harmfully underinclusive and overinclusive. Using rules will fail to incentivize organizations we want to incentivize. And, using rules will fail to deter an unacceptable amount of abusive organizations. Nevertheless, lack of enforcement resources push strongly towards using rules.

What might the values approach recommend? Diver recommends looking at three factors: transparency, congruency, and accessibility. The question is which factor is most important to the goals and the environment in which the law is being applied. Is transparency, congruency, or accessibility the most important factor in charitable organization oversight? While external agency rules should likely be more transparent, and accessible, there is a difference between sanctioning rules and licensing rules. Diver recognizes that licensing regimes tend to need congruency because of the wide range of factors and time that are involved. However, he also recognizes the fact that transparency through rules can help an overwhelmed agency work through its caseload. In the end, Diver's analysis sends us to

Pitt Tax Review | ISSN 1932-1821 (print) 1932-1996 (online) DOI 10.5195/taxreview.2015.41 | http://taxreview.law.pitt.edu 
probably about the same place. For charitable purpose, standards might be ideal. However, enforcement ability strongly pushes in favor of some level of rules - probably simple ones. To the extent charitable tax law is penalizing discrete acts, such as political campaign intervention, there are stronger reasons for the use of transparent rules. Additionally, where it veers into policing fundamental rights, transparent rules may be important and maybe even necessary. ${ }^{204}$

What about the Sunstein approach? While Sunstein also considers many of the same factors as Kaplow and Diver, Sunstein gives some extra thought to the likelihood of bias, the location and nature of social disagreement, the stakes, the quality of those who apply the law, and the alignment or nonalignment of views between lawmakers and others. These factors double in a sense as questions about whether rules are desired and whether there are reasons for the legislature or the agency to develop the rules.

If Congress thinks the IRS is likely to enforce charitable tax law with bias, Congress might want rules over standards. While the recent Tea Party affair might suggest Congress should be concerned about IRS bias, the run of the mill charitable purpose issue is probably not that subject to bias. The IRS itself is fairly insulated from the political process - it only has two political appointees. Also, the vast majority of charitable determinations connect little to politics or religion - the two places Congress is likely to be most concerned about bias. Thus, on the issue of charitable purpose, Congress should expect a relatively unbiased application by the IRS. This would tend toward standards for charitable purpose, but maybe rules for religion and political activities. Of course, again for political reasons, it is also likely very difficult for Congress itself to agree on rules on these matters.

Other Sunstein factors to consider include: the location and nature of the social disagreement, the stakes, the quality of those who apply the law, and the alignment or nonalignment of views between lawmakers and others. The first issue largely boils down to whether the Congress trusts the IRS or judges to apply a charitable standard. The stakes involved are often limited because for many organizations tax exemption does not provide large benefits. An organization that makes no profit experiences no gain from being relieved of paying an income tax. However, the stakes can become quite large when the

\footnotetext{
${ }^{204}$ See Hackney, supra note 20, at 454 (arguing that when the Service is investigating a matter involving fundamental Constitutional rights it should exercise greater care).
}

Pitt Tax Review | ISSN 1932-1821 (print) 1932-1996 (online) DOI 10.5195/taxreview.2015.41 | http://taxreview.law.pitt.edu 
charitable contribution deduction and the other potential benefits that can flow from charitable status are considered. Thus, the stakes involved may point towards some consideration of rules.

The quality of the individuals applying the law is an important factor in charitable organization law. During the Tea Party affair it became evident that there are not enough workers and that the workforce lacks some sophistication. ${ }^{205}$ This factor points towards simple rules in the same way we determined that an overworked agency may need simple rules to manage its workload. Of course, Congress has recently enacted a number of laws constricting the scope of the IRS in applying the laws regarding certain charitable organizations. This is objective evidence that Congress does not trust the IRS in applying the standard correctly without the aid of specific rules.

The Sunstein considerations may tell us something about the desirability of rules, but they are also quite conclusory. If Congress does not trust the enforcer, they may choose to impose rules, even if they are not ideal for a particular situation. Thus, this final set of values to consider seems a little less useful. Nevertheless, this final assessment does suggest that there is some need for rules in this environment. It also leads into the next two questions of who should develop those rules and what form should they take.

\section{Who Should Develop Charitable Rules and What Form Should They Take}

The IRS should generally develop the rules regarding charitable purpose. ${ }^{206}$ This inclination is driven by the fact that the analysis above only came to the conclusion that rules are likely useful in this arena because of an imperfect enforcement environment and lack of sophisticated parties. All things considered, we might prefer standards for charitable purpose.

\footnotetext{
${ }^{205}$ Nicholas Confessore, David Kocieniewski \& Michael Luo, Confusion and Staff Troubles Rife at IRS Office in Ohio, N.Y. TIMES, May 18, 2013 (describing the main IRS office evaluating applications as an "understaffed Cincinnati outpost that was alienated from the broader I.R.S. culture and given little direction").

${ }^{206}$ However, this is only the beginning of an analysis because the issue involves the question of congressional delegation, which is beyond the scope of this article.
}

Pitt Tax Review | ISSN 1932-1821 (print) 1932-1996 (online) DOI 10.5195/taxreview.2015.41 | http://taxreview.law.pitt.edu 
However, since we need rules, how can we best minimize the likely harm from overinclusion and underinclusion?

Congressionally set charitable purpose rules are likely to be problematic for the long-term health of charitable organization law for a number of reasons. Rules set by Congress are highly likely to be reactionary and aimed at solving some charitable abuse problem. ${ }^{207}$ Congress is unlikely to be able to generate the best information in that environment or to enact the type of rules that will not cause harmful overinclusion and underinclusion. Finally, and most importantly, the permanence of rules set at that level would increase the harm of that overinclusiveness and underinclusiveness. Congressional rules are likely aimed at the uncommon situation that Weisbach identified that occurs in tax law at times. In these instances it is likely that rather than bringing clarity, Congress creates much more complexity than would have been needed had it left the imperfect law alone.

The IRS, however, can write rules that provide certainty while maintaining the flexibility necessary for the changing nature of the concept of a charitable purpose. The IRS reviews real cases as they arise. This provides it an informational advantage over Congress that can only access this information through investigations. The IRS can enact useful guidance based on that information that responds to real organizational problems. Additionally, as the facts change over time, the IRS has the flexibility to change those rules or modify them more significantly than if Congress has established strict rules.

As to the final question, the IRS should enact these rules in flexible forms of guidance. Regulations are hard to implement, and are hard to change. Regulations are likely therefore to suffer from the same problems as legislation. The IRS and Treasury should, however, consider using regulations with rules to govern matters of discrete acts such as political campaign intervention and excess benefit transactions. They should leave matters of charitable purpose though at the level of standard in the regulations. Rules regarding charitable purpose can be effectively developed in revenue rulings and revenue procedures where there is a greater level of flexibility.

\footnotetext{
${ }^{207}$ See Troyer, supra note 101 (discussing the tendency of Congress to legislate by anecdote in the charitable realm, leading to harmful law).
}

Pitt Tax Review | ISSN 1932-1821 (print) 1932-1996 (online) DOI 10.5195/taxreview.2015.41 | http://taxreview.law.pitt.edu 
These thoughts and conclusions in this section are limited to an ideal efficiency analysis. An analysis of this matter through the principles of delegation, rather than through just a rules and standards analysis, could change these conclusions regarding form. To complete a full analysis of the legal form we would need to know the level of deference courts should provide to these products. Courts appear to be quite confused as to what deference if any that they should give to these forms of guidance. ${ }^{208}$ If these forms of guidance are provided limited or no deference, we might think differently about whether flexible forms of guidance are ideal. Thus, more work needs be done.

With all of this said, Congress is likely the best rulemaker in a few instances. First, where there is a need to prescribe certain conduct such as inurement or engaging in political activities as discussed in Part IV.C, it makes perfect sense for Congress to set these rules. We have no strong reason to believe that ideas regarding inurement or political activities are likely to substantially change or to be highly complex in the way that charitable purpose is likely to be highly complex. This is also likely to apply in situations such as UBIT and excess benefit transactions. The activity being prescribed in both are relatively straightforward taxable transactions. Congressionally set rules, therefore can provide certainty in these areas where there is likely little change over time. This can be helpful to the IRS because of the fact that penalties and high dollar amounts are often owed in these circumstances.

Second, there may be a place for Congress to enact procedural rules that make organizations engage in charitable behavior and makes it easy for the IRS to verify. It is doubtful that the IRS has the authority to impose such procedures or, even if it does, that it would use that authority, without the express statutory authority of Congress. These come though with no insurance that charitable conduct will be better, and they increase the costs of complying with the charitable regime. Congressional establishment of these types of rules though does not conflict with the need for flexibility in defining charitable purpose, because it does not define charitable purpose; it only sets a procedure for determining whether the organization is operating for that charitable purpose.

${ }^{208}$ Hickman, supra note 17, at 469-70.

Pitt Tax Review | ISSN 1932-1821 (print) 1932-1996 (online) DOI 10.5195/taxreview.2015.41 | http://taxreview.law.pitt.edu 


\section{4 | Pittsburgh Tax Review | Vol. 132015}

Finally, given the resource challenges faced by the IRS in its exempt organization division, Congress should consider rules that limit the organizations that qualify for charitable status. If Congress finds a category of organization that is of highly questionable qualification as a charitable organization, it probably makes good sense to enact a simple rule to remove the organization from charitable status. Congress did this for insurance companies by enacting $\S 501(\mathrm{~m})$. That probably simplified the IRS oversight role significantly. As discussed below, such a choice might make sense for hospitals too.

\section{ANALYSIS OF RECENT LEGISLATION}

In light of the above analysis, what can we say about the effectiveness of the recent credit counseling, hospital, and supporting organization legislation? Congress tended towards the rule side of the rule/standard continuum in these efforts. Obviously, the claim here is that congressional rules can be expected to be harmful to charitable oversight. Does that analysis hold up here?

The credit counseling legislation is likely to be harmful to compliance and oversight, because it largely focused on matters of charitable purpose. These rules are likely to cause harmful overinclusion and underinclusion. The supporting organization legislation and hospital legislation will likely come with problems, but may be saved in part by using procedural rules that clearly apply to distinct segments of sophisticated charitable organizations. However, all of these rules added complexity without likely improving organizational behavior. It is unclear that any benefits outweigh the costs of the complexity and the underinclusion and overinclusion involved.

\section{A. Credit Counseling Legislation}

\section{Credit Counseling Legislation}

The IRS began to publicly evaluate the credit counseling industry and its use of charitable tax-exempt status in the early 2000s. ${ }^{209}$ A credit counseling organization operates to educate the public on debt management

\footnotetext{
${ }^{209}$ I.R.S. News Release, IR-2003-120 (Oct. 14, 2003); I.R.S. News Release, IR-2006-80 (May 15, 2006).
}

Pitt Tax Review | ISSN 1932-1821 (print) 1932-1996 (online) DOI 10.5195/taxreview.2015.41 | http://taxreview.law.pitt.edu 
and also to assist debtors in negotiating with creditors to establish a plan to get out of debt. At that time, the FTC and state regulators were worried that these organizations were taking advantage of consumers. ${ }^{210}$ Often, rather than helping individuals get out of debt, some of these organizations made a debtor's situation worse. The IRS had recognized the vast majority of this industry as charitable, and therefore, exempt from income tax. There were only 200 credit counseling organizations in 1990 . However, by the early 2000 s that number had expanded to over $1,000 .{ }^{211}$ This increase might have been the result of legislation passed by Congress in 1996 that restricted credit repair organizations from acts perceived as abuses of debtors, but exempted from the law credit repair organizations that qualified as charitable organizations under the Code. ${ }^{212}$

The IRS ruled in 1965 that an organization that assisted individuals with bad debt could qualify as a tax-exempt social welfare organization under $\S 501(\mathrm{c})(4)$, but not as a charitable organization. ${ }^{213}$ While social welfare organizations are exempt from tax, donors can only deduct their contributions to a charitable organization. ${ }^{214}$ In 1969 , the IRS ruled that an organization that educates consumers about credit and helps low-income individuals manage bad credit could qualify as a charitable organization. ${ }^{215}$

This rule changed though after the IRS lost a case against an Alabama organization that helped both low-income and middle-class individuals for a fee. ${ }^{216}$ The court held that the organization was educational. It further held

\footnotetext{
${ }^{210}$ I.R.S. News Release, IR-2003-120 (Oct. 14, 2003); I.R.S. News Release, IR-2006-80 (May 15, 2006).

${ }^{211}$ JOINT COMM. ON TAXATION, supra note 94.

212 Debra Cowen \& Debra Kawecki, Credit Counseling Organizations, in EXEMPT ORGANIZATIONS CONTINUING PROFESSIONAL EDUCATION TEXT (2004) (seeming to attribute the increase in credit counseling "agencies" and "repair organizations" to the passing of the Credit Repair Organizations Act, Pub. L. No. 104-208, § 2451, 110 Stat. 3009-455 (1996)).

${ }^{213}$ Rev. Rul. 65-299, 1965-2 C.B. 165.

${ }^{214}$ I.R.C. $\S 170$.

${ }^{215}$ Rev. Rul. 69-441, 1969-2 C.B. 115; see I.R.S. Gen. Couns. Mem. 2004-31-023 (July 30, 2004) (discussing the IRS guidance history regarding credit counseling organizations).

${ }^{216}$ Consumer Credit Counseling Serv. of Ala., Inc. v. United States, 78-2 U.S.T.C. $\uparrow 9660,44$ A.F.T.R.2d 79-5122 (D.D.C. 1978); see Cowen \& Kawecki, supra note 212.
}

Pitt Tax Review | ISSN 1932-1821 (print) 1932-1996 (online) DOI 10.5195/taxreview.2015.41 | http://taxreview.law.pitt.edu 


\section{6 | Pittsburgh Tax Review | Vol. 132015}

that the specific debt management assistance was an integral part of the educational activity of the organization. Finally, because the IRS argued that the credit counseling organization could not charge a fee for these services, the court held that a charitable organization is not required to provide services to low income individuals for free. ${ }^{217}$

The IRS, the FTC, and state regulators announced in 2003 that they were all taking a closer look at credit counseling organizations, and warned consumers about engaging in business with these organizations. ${ }^{218}$ The IRS also issued a series of legal opinions ${ }^{219}$ and examined a significant segment of the credit counseling industry holding tax-exempt status. ${ }^{220}$ The IRS revoked the tax-exempt statuses of a large segment of the credit counseling industry because these organizations were not properly conducting activities for the public benefit. ${ }^{221}$ The primary attacks of the IRS in this round were to claim that the organizations did not conduct education and that they were operated for the private benefit of organization operators.

In 2006, concerned about the same abuses perceived by the IRS and the FTC, Congress enacted $\S 501$ (q) to apply specific requirements to "credit counseling organizations" that qualify as charitable or social welfare organizations under the Code. ${ }^{222}$ In the new law, described above in Part II.C, Congress placed far more restrictions on charitable credit counseling organizations than it had placed on any other charitable industry sector. The primary goal of the law was to protect consumers who seek help in repairing credit. Among other matters, it prohibited or limited activities that were subject to particular abuse such as loans to debtors, fees charged for debt management plans, and fees for a referral to another organization. Taking note of the fact that the IRS had been successful in attacking some of these

\footnotetext{
${ }^{217}$ Id. at $85,191,44$ A.F.T.R.2d at 59-5124.

${ }^{218}$ I.R.S. News Release, IR-2003-120 (Oct. 14, 2003).

${ }^{219}$ I.R.S. Legal Mem. 2004-31-023 (July 30, 2004); I.R.S. Legal Mem. 2006-20-001 (May 19,

${ }^{220}$ Internal Revenue Serv., Credit Counseling Compliance Project (2006), available at http://www.irs.gov/pub/irs-tege/cc_report.pdf.

${ }^{221}$ IRS Takes New Steps on Credit Counseling Groups Following Widespread Abuse, I.R.S. NEWS Release, May 15, 2006, available at https://www.irs.gov/pub/irs-news/ir-06-080.pdf.

${ }^{222}$ Pension Protection Act of 2006, Pub. L. No. 109-280, 120 Stat. 780.
} 2016).

Pitt Tax Review | ISSN 1932-1821 (print) 1932-1996 (online) DOI 10.5195/taxreview.2015.41 | http://taxreview.law.pitt.edu 
abuses, the Joint Committee on Taxation Explanation suggests that the new legislation is entirely consistent with prior IRS action and guidance, and only enhanced the IRS efforts. ${ }^{223}$

Congress defined credit counseling organization functionally. The rules apply to an organization that provides "substantial" "credit counseling services" that is trying to qualify and maintain status as a charitable or social welfare organization. ${ }^{224}$ Congress defined credit counseling services broadly to include "the providing of educational information to the general public on budgeting, personal finance, financial literacy, saving and spending practices, and the sound use of consumer credit," or "the assisting of individuals and families with financial problems by providing them with counseling." 225

The IRS has issued neither regulations nor revenue rulings on this set of rules for credit counseling organizations. However, it has engaged in litigation. ${ }^{226}$ It also issued a Program Manager Technical Advice Memorandum on whether an organization providing advice to homeowners on debt needed to abide by the new rules. ${ }^{227}$ It found that the definition of credit counseling applied broadly. Instead of the rules applying only to traditional credit counseling organizations, the rules applied to organizations assisting homeowners in potential foreclosure situations.

The credit counseling legislation fails on a number of levels. First, Congress enacted rules regarding charitable purpose, which according to the above analysis should be problematic. Second, it passed complex rules for a very small number of organizations. Third, Congress wrote the legislation broadly such that it likely impacts many groups that Congress did not intend to impact. Finally, Congress implemented rules that should be applicable to the industry as a whole, not just those that qualify as tax-exempt. This final one is admittedly not exactly about rules versus standards.

\footnotetext{
${ }^{223}$ JOINT COMM. ON TAXATION, supra note 94.

${ }^{224}$ I.R.C. $\S 501(\mathrm{q})$.

${ }^{225} \mathrm{Id}$.

${ }^{226}$ See, e.g., Cambridge Credit Counseling Corp. v. Comm'r, No. 27495-11, 2011 WL 6399713 (T.C. Nov. 30, 2011).

${ }^{227}$ I.R.S. Gen. Couns. Mem. 101,470 (Mar. 30, 2010).
}

Pitt Tax Review | ISSN 1932-1821 (print) 1932-1996 (online) DOI 10.5195/taxreview.2015.41 | http://taxreview.law.pitt.edu 
Fundamentally, the problem with this legislation is that it imposed rules on a matter of charitable purpose. Congress tried to define the acts that make a particular industry organization charitable or not. Given the analysis above, we should expect this effort to be one of folly, and one that will result in harmful overinclusion and underinclusion. It should lead to inefficiencies in the provision of charitable services. The law will discourage efforts that might have fit the charitable ideal while likely allowing efforts that do not fit the charitable ideal. A number of other matters compound this problem though.

At the time of the legislation about 1,000 organizations qualified as credit counseling organizations. In a relative sense, this is a very small number of total charitable organizations. Using the Kaplow analysis, this was likely an inefficient place for Congress to make rules. Because there were a small number of organizations, it was probably better in a cost sense to rely more on case-by-case means of analysis. As discussed above, the IRS is probably the better party to make the rules on charitable purpose for credit counseling organizations.

But this inefficiency is likely not the only problem with legislating for a small group. In effect, Congress sought to shut down uncommon situations. This effort is likely to lead to the problems identified by Weisbach in making the uncommon common. While Congress might succeed in stopping the abuses that it was able to anecdotally observe, it likely opened doors for abuses we are yet to see.

As discussed above, the IRS was already taking on this industry and having some success. It would have been far better to allow the IRS to reign in the industry as best as possible. The overall increase of complexity to the charitable sector with the addition of these complex rules for a small group of organizations was not worth it.

As identified above, a problem with developing rules for sophisticated organizations is that those rules, if not cabined properly, might end up causing harm to the unsophisticated part of the sector. Credit counseling organizations largely seem to be sophisticated organizations with substantial amounts of money. Thus, rules might have made sense if Congress could successfully limit the complexity to that sector alone. The definition of "credit counseling organization," however, is so broad that many organizations outside credit counseling organizations will need to determine whether the rules apply to them. This is costly and may have the bad effect that organizations choose not to seek guidance because of the costs involved.

Pitt Tax Review | ISSN 1932-1821 (print) 1932-1996 (online) DOI 10.5195/taxreview.2015.41 | http://taxreview.law.pitt.edu 
A further potential problem of the broad definition is that it may result in the IRS choosing not to apply the law in all applicable circumstances. This might happen if the law technically applies to an organization that helps students with student loans, but its application would cause harm to that organization's operation. It may not be in the IRS's political interest to apply this legislation broadly to activities beyond the traditional credit counseling organizations. Although these choices are likely to be based in the practical reality of enforcement, this creates real rule of law problems.

Additionally, this legislation is truly focused on consumer protection rather than charitable purpose. The IRS is probably not the best agency to handle these matters. Perhaps the FTC would be the better agency. Providing consumer protection jurisdiction to the IRS could result in the laws being less effective than if placed in a more logical location such as the FTC. The legislation directs the IRS's attention away from charitable tax law. Following the rule of thumb of this article that Congress should stick to standards in charitable tax law would have stopped Congress from moving to impose rules in an area where they are not the most efficient creators of such rules.

Finally, many of the ideas Congress adopted to apply to credit counseling organizations might be broad principles that could be adopted and applied to charitable organizations generally. Applying those principles narrowly leaves a confusing muddle of the law because it calls into question whether those principles have any application in other areas now. For example, the requirement of a community board is something that the IRS often considers as a factor in determining whether an organization is charitable. Applying it in such a narrow context limits its economy as a rule and may even lead to conclusions that it is not even a factor in assessing other charitable organizations. This would be an unfortunate consequence of the rule.

The point here is not that there should be no credit counseling organization rules. Instead, Congress probably failed in its drafting of rules for credit counseling organizations because it is a bad institution to generate the rules necessary to govern such organizations. There is so much complexity involved in credit counseling activities that rules generated at the IRS based on case-by-case knowledge are likely to achieve greater congruency than those by Congress. What should Congress do instead? Not pass legislation. For matters of charitable purpose, Congress should stick to broad standards and allow the IRS to organically develop any needed rules.

Pitt Tax Review | ISSN 1932-1821 (print) 1932-1996 (online) DOI 10.5195/taxreview.2015.41 | http://taxreview.law.pitt.edu 


\section{0 | Pittsburgh Tax Review | Vol. 132015}

There are ways that Congress can make its interests known to the IRS. It can hold hearings, conduct research, and communicate concern to the IRS, all without passing legislation.

\section{B. Hospitals}

The IRS has long held that nonprofit hospitals generally qualify as taxexempt charitable organizations under $\S 501(\mathrm{c})(3) .{ }^{228}$ Although originally this status was based upon a hospital providing a substantial amount of charity care, ${ }^{229}$ the IRS changed that standard in 1969 to a community benefit standard. ${ }^{230}$ In that ruling, the IRS ruled that a hospital that, inter alia: (1) was open to all in the community who could pay; (2) operated an emergency room that treated all patients without regard to ability to pay; (3) maintained a board representative of the community; and (4) generally dealt fairly with its doctors could qualify for charitable status. ${ }^{231}$ While there were other ways to qualify, this came to be known generally as the community benefit standard.

Many criticize the community benefit standard because it allows almost any hospital to qualify as a charitable organization. ${ }^{232}$ The primary critique is that there is no difference between most nonprofit and for-profit hospitals to justify treating one as exempt from taxation and not the other. Because nonprofit hospitals provide very similar services and also treat patients in very similar ways, there is no reason to provide a subsidy to these organizations goes the argument. Professor Hansmann, for instance, argues that for profit hospitals would likely be more efficient in an economic sense than their nonprofit counterparts. ${ }^{233}$ Some have made the case though that

${ }^{228}$ Rev. Rul. 56-185, 1956-1 C.B. 202; Rev. Rul. 69-545, 1969-2 C.B. 117.

${ }^{229}$ Rev. Rul. 56-185, 1956-1 C.B. 202.

${ }^{230}$ Rev. Rul. 69-545, 1969-2 C.B. 117.

${ }^{231} I d$.

${ }^{232}$ See Hall \& Colombo, supra note 186, at 52; Hansmann, supra note 22; see E. Ky. Welfare Rights Org. v. Shultz, 370 F. Supp. 325 (D.D.C. 1973), rev'd sub nom. E. Ky. Welfare Rights Org. v. Simon, 506 F.2d 1278 (D.C. Cir. 1974), vacated sub nom. Simon v. E. Ky. Welfare Rights Org., 426 U.S. 26 (1976).

${ }^{233}$ Hansmann, supra note 22, at 75 (contending that nonprofit hospitals are likely overcapitalized as compared to their for-profit counterparts).

Pitt Tax Review | ISSN 1932-1821 (print) 1932-1996 (online) DOI 10.5195/taxreview.2015.41 | http://taxreview.law.pitt.edu 
nonprofit hospitals do provide some good by providing services that would otherwise not be provided as sufficiently by for-profit hospitals. ${ }^{234}$

In the same way that Senator Grassley spurred the IRS into action on both supporting organizations and credit counseling organizations, Grassley nudged the IRS to look closer at hospitals, too. In 2009, the IRS released a report on hospitals. ${ }^{235}$ The IRS sent out a questionnaire to more than 500 nonprofit hospitals to find out about the sector's operations. The IRS was able to draw limited conclusions from the information it generated. It conducted audits of a number of hospitals that were outliers in executive compensation. ${ }^{236}$ This significant review of the hospital sector did not result in any substantive changes in the IRS position on hospitals. However, the IRS implemented a new schedule for hospitals on the Form 990 called Schedule $\mathrm{H}^{237}$ On that form, the IRS requires hospitals to describe the charity care they provide, the joint ventures they have entered, and the deals in which they have engaged with insiders.

The IRS has spent substantial time implementing regulations regarding these new rules for hospitals. ${ }^{238}$ The fact that the IRS has spent time promulgating regulations suggests that this new law might be a little less on the rule end of the spectrum than the credit counseling law. A direct command to establish a written financial assistance policy falls on the rule side, and while a requirement to conduct a CHNA is much more rule oriented than operating for a charitable purpose, it left a lot to be defined.

${ }^{234}$ Jill R. Horwitz, Why We Need the Independent Sector: The Behavior, Law, and Ethics of Notfor-Profit Hospitals, 50 UCLA L. REV. 1345 (2003).

${ }^{235}$ IRS NonProfit Hospital Project-Final RePORT (Sept. 1, 2015), http://www.irs.gov/ Charities-\&-Non-Profits/Charitable-Organizations/IRS-Nonprofit-Hospital-Project-Final-Report.

${ }^{236}$ Lois Lerner, Dir., I.R.S. Exempt Orgs. Div., Statement on the IRS Report on Nonprofit Hospitals at a Press Briefing (Feb. 12, 2009), available at http://www.irs.gov/pub/irs-tege/lernerstatement hospitalproject_021209.pdf.

${ }^{237}$ Dep'T of the Treasury, Internal Revenue Serv., Schedule H (Form 990) (2015), available at http://www.irs.gov/pub/irs-pdf/f990sh.pdf.

${ }^{238}$ Additional Requirements for Charitable Hospitals; Community Health Needs Assessments for Charitable Hospitals, T.D. 9708, 2015-5 C.B. 80; Requirement of a Section 4959 Excise Tax Return and Time for Filing the Return; Correction, T.D. 9629, 2013-1 C.B. 78.

Pitt Tax Review | ISSN 1932-1821 (print) 1932-1996 (online) DOI 10.5195/taxreview.2015.41 | http://taxreview.law.pitt.edu 
Hospitals are the largest sector of charitable organizations by asset size. ${ }^{239}$ Thus, good rules, even if complex, arguably would be useful to govern this sector. The analysis above would suggest, though, that it would be better if the IRS, rather than Congress, drafted these rules. How does the new hospital legislation fare under the analysis?

The hospital legislation was less complex than the credit counseling legislation and utilized more procedural-like rules as opposed to behavioral rules. For instance, the CHNA is a mandated process that the hospital must perform rather than an activity it must do to be charitable in and of itself. ${ }^{240}$ The focus on procedure rather than organizational behavior likely allowed relatively transparent and accessible rules. In considering the need for rules from an administrative standpoint, process-oriented rules are likely particularly useful. There is little subjectivity in these rules. Organizations can follow the rules, and the IRS can relatively easily administer them.

Nevertheless, it is not clear that these new rules will change behavior in a positive manner. Obviously reviewing charitable needs of the community and reporting on them does not ensure that the hospital operates more charitably. Additionally, these rules add extra work and complexity to charitable law for hospitals. Hospitals already have an obligation imposed by the IRS to provide fairly significant public disclosure regarding their activities through the Form 990 and Schedule H. In spite of all of this disclosure there is still frustration with the hospital sector. It is hard to believe that the answer really lies in more disclosure.

Thus, Congress increased the costs of both regulating and complying without clear substantive benefits in return. Rather than encouraging hospitals to become better actors, these provisions may have the perverse result of decreasing compliance. Some may choose not to seek counsel because they are spending time doing busy work complying with Code provisions. The new rules will also increase rule interactions making compliance more costly.

These rules will also increase the regulatory costs of the IRS. None of these new provisions is a substitute for the old law. There is nothing about the process or the requirements that organizations had to do before these

\footnotetext{
${ }^{239}$ See McKeever \& Pettijohn, supra note 64.

${ }^{240}$ See Colinvaux supra note 4 , at 51 (discussing the fact that Congress used a particularly processoriented approach for the hospital legislation).
}

Pitt Tax Review | ISSN 1932-1821 (print) 1932-1996 (online) DOI 10.5195/taxreview.2015.41 | http://taxreview.law.pitt.edu 
provisions, and it is unlikely that they will serve as substitutes for the community benefit test. Perhaps the CHNA helps provide a tool for the IRS to ensure that the community benefit standard is being met, but it is still an extra step. Further compounding the extra costs on the IRS is that Congress now requires the IRS to audit a hospital once every three years. This is a rule about agency resources. Diver in particular has suggested that standards are better in terms of the allocation of scarce agency resources. A regulatory cost here may be that the IRS may be forced to allocate too many resources to hospitals, and away from other important sectors.

Congress should consider applying the broad principles it is seeking to inculcate through this legislation outside of the tax regime or more broadly within charitable tax law. First, Congress should consider enacting the credit policies on all hospitals, not just the charitable ones. Realistically, those are more about consumer protection than about charitable purpose. Using charitable tax law unnecessarily complicates that law and fails to apply the principle to all organizations to which the law should apply. Second, there might be rules that should be applied more broadly to charitable organizations. This would be a more economical use of rules. If it is the conclusion that hospitals objectively will behave more charitably if forced to annually file a community benefit report, perhaps this should be applied to all charitable organizations.

Finally, Congress could have considered eliminating hospitals altogether as Congress did with insurance companies. ${ }^{241}$ This could simplify the challenge of managing charitable organizations and it may also improve charitable oversight by eliminating a part of charitable law that leads to incongruity with ideal charitable law. There are many who have called for hospitals to lose charitable status for lack of fit with the charitable ideal. A taxing regime applied to hospitals, although complex, would arguably be a simpler regime to enforce. Of course, there would be hospitals that would continue to apply, but they would not need the promotion of health to do so. Hospitals that are operated to provide substantial care for free to the poor would continue to qualify, as likely would those that engage in substantial research or teaching.

${ }^{241}$ I.R.C. $\S 501(\mathrm{~m})$.

Pitt Tax Review | ISSN 1932-1821 (print) 1932-1996 (online) DOI 10.5195/taxreview.2015.41 | http://taxreview.law.pitt.edu 


\section{4 | Pittsburgh Tax Review | Vol. 132015}

What should Congress do instead? Not act. Hospital behavior is likely to be about the same as before, but simply subject to greater costs. Thus, it would be better to have left the state of the law as it is - as a standard. Alternatively, eliminating hospitals from tax exemption could have enhanced the oversight of charitable organizations by removing a huge destabilizing sector from the regime. Hospitals would then be taxable, which comes with complexity, but a complexity that the IRS is much more prepared to handle. Finally, consider ways to apply the procedural principles more broadly whether within charitable tax law or in law more appropriate to the matter at hand.

\section{Supporting Organizations}

In 1969, Congress significantly changed charitable organization law. ${ }^{242}$ Congress passed strict rules to apply to private foundations, which were defined in a negative manner as any charitable organization that did not qualify as a public charity. ${ }^{243}$ Public charities include recognized community organizations such as hospitals, churches, or schools, ${ }^{244}$ and also organizations that receive broad public support. ${ }^{245}$ All other charitable organizations are classified as private foundations. A private foundation tends to receive the vast majority of its support from one family or a small group of families. Congress imposes highly restrictive rules on private foundations. ${ }^{246}$ Additionally, a private foundation is not able to offer as valuable of a charitable contribution deduction to its donors as it could if it were a public charity. ${ }^{247}$

\footnotetext{
${ }^{242}$ Tax Reform Act of 1969, Pub. L. No. 91-172, 83 Stat. 487. For a discussion of the changes made, see Homer C. Wadsworth, Private Foundations and the Tax Reform Act of 1969, 39 LAW \& CONTEMP. PROBS. 255 (1975).

${ }^{243}$ I.R.C. $§ 509$.

${ }^{244} I d . \S 509(\mathrm{a})(1)$.

${ }^{245}$ Id. $\S 509$ (a)(1) \& (2).

${ }^{246} I d . \S \S 4941-4945$.

${ }^{247}$ Id. $\S 170$.
}

Pitt Tax Review | ISSN 1932-1821 (print) 1932-1996 (online) DOI 10.5195/taxreview.2015.41 | http://taxreview.law.pitt.edu 
Congress though provided a means to avoid private foundation status: form an organization to "support" a public charity. ${ }^{248}$ Under section 509(a)(3), the family foundation seeking supporting organization status must meet several tests. The key test is the relationship test. Under that test the organization must be operated, supervised or controlled by or in connection with one or more public charities. ${ }^{249}$

The IRS enacted some of its most complex regulations ${ }^{250}$ to stem abuses of the supporting organization structure. A supporting organization looks much like a private foundation. Like private foundations, the biggest concern is that a wealthy individual might put significant funds into the supporting organization, take a large deduction, and yet pay little in actual money to charity. In other words, the structure potentially allows a charitable deduction without a real charitable contribution.

In the late 1990s, the media placed a spotlight on the abuse of supporting organizations. One national article pointed to cases such as that of Gerry Spence, who contributed a ranch to a supported organization and continued to use the place for his own purposes. ${ }^{251}$

Type I supporting organizations must establish a legal relationship with a supported organization similar to a parent-subsidiary relationship. ${ }^{252}$ In other words, in the Type I structure, a public charity appoints the board of the supporting organization. In that way, a public charity controls the actions of the supporting organization, and Congress can generally expect the organization to behave in the interest of the public charity rather than the wealthy donor. A Type II supporting organization is said to establish a brother-sister-like corporate relationship with its supported

\footnotetext{
${ }^{248} I d . \S 509(\mathrm{a})(3)$.

${ }^{249} \S 509(\mathrm{a})(3)$.

${ }^{250}$ See, e.g., Windsor Found. v. United States, 77-2 U.S.T.C. 9 9709, 40 A.F.T.R.2d 6004 (E.D. Va. 1977) (stating that "the Internal Revenue Service has drafted fantastically intricate and detailed regulations in an attempt to thwart the fantastically intricate and detailed efforts of taxpayers to obtain private benefits from foundations while avoiding the imposition of taxes").

${ }^{251}$ Monica Langley, Gimme Shelter: The SO Trend: How to Succeed in Charity Without Really Giving - A 'Supporting Organization' Lets the Wealthy Donate Assets, Still Keep Control—Carl Icahn's School Project, Wall St. J., May 29, 1998, at A1.

${ }^{252}$ Supporting Organizations—Requirements and Types, supra note 90.
}

Pitt Tax Review | ISSN 1932-1821 (print) 1932-1996 (online) DOI 10.5195/taxreview.2015.41 | http://taxreview.law.pitt.edu 
organization(s). ${ }^{253}$ This means the same people that control the supported organization control the supporting organization. That leaves Type III supporting organizations. In a Type III structure, there is no direct control by a supported organization or supported organizations. ${ }^{254}$ The supported organization instead typically has what is referred to as a significant voice in the decisions of the supporting organization. ${ }^{255}$

In its report, the Panel on the Nonprofit Sector singled out the Type III structure as particularly subject to abuse. The Panel recommended imposing a payout requirement on Type III supporting organizations to ensure the supporting organization distributed a significant amount of money to its supported organization. ${ }^{256}$ The report stated: "a donor may inappropriately maintain de facto control over a Type III supporting organization and then cause it improperly to provide private benefits." 257

The new rules described above in Part II.C show that Congress tried to stop the abuse of the Type III structure in particular. The IRS has spent significant time providing guidance regarding these new supporting organization rules. It issued a notice about the new requirements, an advanced notice of proposed rulemaking, a notice of proposed rulemaking, and a final regulation along with another notice of proposed rulemaking. ${ }^{258}$

The supporting organization legislation is not about charitable purpose. It instead focuses on organizational structure and behavior. Thus, Congress here avoided the trap of legislating on charitable purpose. Also, there are a large number of supporting organizations and they hold a lot of assets. ${ }^{259}$ These rules are additionally fairly well confined to a narrow circumstance

${ }^{253} I d$.
${ }^{254} I d$.
${ }^{255}$ Id.
${ }^{256}$ PANEL ON THE NONPROFIT SeCtOR, StRENGTHENING TRANSPARENCY, GOVERNANCE,

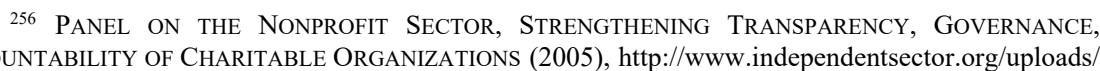
ACCOUNTABILITY OF CHARITABLE ORGANIZATIONS (2005), http://www.independentsector.org/uploads

${ }^{257} \mathrm{Id}$.

${ }^{258}$ For a discussion of this regulatory history, see the preamble to T.D. 9605, 2013-11 I.R.B. 587.

${ }^{259}$ In 2005 over 40,000 supporting organization reported over $\$ 36$ billion in assets. KENNETH T. Wing, Thomas H. POllaK \& AMY BlackWOOD, THE NONPROFit AlmanaC OF 2008, 146, tbl.5.5 (2008).

Pitt Tax Review | ISSN 1932-1821 (print) 1932-1996 (online) DOI 10.5195/taxreview.2015.41 | http://taxreview.law.pitt.edu 
that mostly sophisticated taxpayers will encounter. Thus, legislating here, if sufficiently focused could be a real help.

It is difficult to assess whether these rules will help in terms of compliance and regulation. The overall mix seems to significantly complicate both compliance and regulation. This may be a good thing. Rules prohibiting loans to substantial contributors are bright line rules that are easy to comply with and easy to apply. Rules that require a supporting organization to provide notice to its supporting organizations are also common sense easy to apply rules. These are transparent and likely work toward the intended goal of the law. It is also possible that imposing a payout requirement on certain Type III supporting organizations reduced complexity because it eliminates uncertainty for grantmaking organizations. However, the payout regulations themselves are highly complex too. The other additional rules tended to add total requirements to the already complex system.

The most likely problem with these rules is that they might have been designed to stop the charitable abuse of yesterday rather than today. They were built to stop abuses Congress observed anecdotally. If that is the case, then these rules unnecessarily complicated the law without pushing more money to charitable purposes.

These rules are also an example of the politics of rulemaking. Because Congress did not have the political capital to pass a statute imposing a significant payout requirement on Type III supporting organizations, it instead asked the IRS to determine that amount. Ultimately that became a political problem for the President's administration, and again, politically, the payout was set at a very low level.

Given the complexity involved in regulating these organizations, it is likely that instead of maintaining the structure in full, the best solution here was to eliminate Type III supporting organizations, and significantly reduce complexity.

\section{CONCLUSION}

There is a strong political desire to stop abuses of charitable organizations through the IRS. Congress is inclined to pass legislation that appears tough on those who abuse charities. But, Congress can cause harm to the regulation of the charitable sector when it enacts detailed rules regarding charitable purpose. Although a congressman may find problems in

Pitt Tax Review | ISSN 1932-1821 (print) 1932-1996 (online)

DOI 10.5195/taxreview.2015.41 | http://taxreview.law.pitt.edu 
the sector, the congressman should be reticent to enact rules. He should allow the system to develop organically instead. He should stick to standards and generally stay away from rules at the statutory level. However, if the congressman wants to enact rules, he should look for discrete acts and broad application.

The complexity, diversity, and the changing nature of the charitable ideal suggest that standards should rule charitable tax law. Additionally, that the charitable ideal is based in part on supporting diverse and new ideas commends the use of standards. Rules defining charitable purpose are likely to cut off this diversity-enhancing goal of the charitable ideal. However, a number of factors point toward rules. There are a large number of charitable organizations and many are unsophisticated. Providing rules in this context could ensure greater compliance. The sophisticated charities have significant amounts of money. Again, it might be worth the upfront costs to generate rules for these organizations given the dollars involved. Finally, and maybe most importantly enforcement resources are not adequate for oversight. Rules may be the only way to make the lack of enforcement resources functional. Thus, despite the initial sense that rules are not ideal to govern the charitable ideal, they are needed to make oversight possible.

While these factors point in different directions, in order to best maintain the charitable ideal, Congress should generally stick to standards for legal commands regarding charitable purpose. It should allow the IRS to enact flexible rules that are informed by its daily case-by-case analysis. To maintain that flexibility, the IRS should stick to more flexible forms of guidance such as revenue rulings and procedures rather than regulations. These conclusions regarding who should enact rules and what form those rules should take are based on a rules versus standards analysis alone. To make a more informed conclusion we need a thorough analysis of the issue of delegation by Congress in the charitable tax law arena and the degree of deference courts should extend to different forms of charitable tax law guidance. These issues are beyond the scope of this article though.

This analysis, however, does suggest that Congress can usefully enact rules on discrete acts of charitable organization personnel. Thus, Congress would be well advised to enact rules for political campaign intervention and matters related to inurement. Additionally, Congress should consider enacting some rules that it applied only to credit counseling organizations more broadly. For instance, the requirement of a community board could be usefully extended to all charitable organizations. Only applying it to one narrow sector likely causes harm to charitable law generally. Additionally,

Pitt Tax Review | ISSN 1932-1821 (print) 1932-1996 (online)

DOI 10.5195/taxreview.2015.41 | http://taxreview.law.pitt.edu 
Congress should consider whether relatively easily administered procedural rules, such as the CHNA requirement imposed on hospitals, would be a positive move for oversight and compliance. Given that there is already substantial reporting on Form 990, it is hard to imagine additional reporting could have this effect, but it is worth consideration because of its easy use.

These recommendations are no panacea for charitable organization oversight. The only claim here is that this best balances the current oversight and compliance environment challenges. It also makes the claim that efforts to improve oversight by enacting new restrictive rules on charitable purpose can be expected to backfire.

Finally, to make this recommendation work, the IRS needs to allocate more resources towards enacting useful publicly available rules on matters of charitable purpose. The IRS tends to move slowly. It will have to do better in this regard. But, a message of this article is that spending its resources in this way is likely to pay dividends to the IRS on the enforcement end.

Pitt Tax Review | ISSN 1932-1821 (print) 1932-1996 (online) DOI 10.5195/taxreview.2015.41 | http://taxreview.law.pitt.edu 